•综述・

\title{
附生濒类植物的克隆性研究进展
}

\author{
孙晶琦 1,2 陈 泉 ${ }^{2}$ 李航宇 2,3 常艳芬 ${ }^{4}$ \\ 巩合德 ${ }^{1}$ 宋 亮 ${ }^{2}$ 卢华正 ${ }^{2 *}$ \\ 1 (西南林业大学地理与生态旅游学院, 昆明 650224) \\ 2 (中国科学院西双版纳热带植物园热带森林生态学重点实验室, 云南敌腊 666303) \\ 3 (普洱学院生物与化学学院, 云南普洱 665000) \\ 4 (衡阳师范学院生命科学与环境学院, 湖南衡阳 421008)
}

摘要: 石松类及藓类植物在高等植物中处于比较特殊的进化与系统发育地位, 同时具有孢子植物(孢子)与种子植

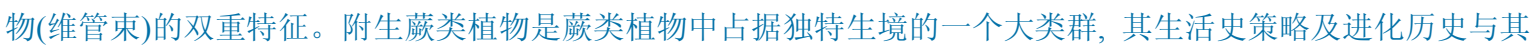
附生生长的森林生态系统紧密相关。大部分附生藓类植物的克隆生长习性及克隆生活史性状在其生态适应中具有 重要作用, 但这方面未引起广泛关注。本文主要综述了中国山地森林中附生藓类植物的根状茎克隆生长、克隆性 与生态适应性、不同克隆生长方式与进化等方面, 并展望了茨类植物克隆性在森林生态系统过程与功能中的作用, 以及今后如何将莊类植物生态学研究与气候变化、植被恢复、土地利用变化等全球变化的主流方向进行结合。

关键词：荻类植物; 林冠; 附生植物; 克隆性; 森林生态系统; 生态功能

\section{Progress on the clonality of epiphytic ferns}

Jingqi Sun ${ }^{1}$, Quan Chen ${ }^{2}$, Hangyu Li ${ }^{2,3}$, Yanfen Chang ${ }^{4}$, Hede Gong ${ }^{1}$, Liang Song ${ }^{2}$, Huazheng Lu $^{2 *}$

1 School of Geography and Ecotourism, Southwest Forestry University, Kunming 650224

2 CAS Key Laboratory of Tropical Forest Ecology, Xishuangbanna Tropical Botanical Garden, Chinese Academy of Sciences, Mengla, Yunnan 666303

3 College of Biology and Chemistry, Pu'er University, Pu'er, Yunnan 665000

4 College of Life Sciences and Environment, Hengyang Normal University, Hengyang, Hunan 421008

\begin{abstract}
Lycophytes and ferns display dual life-history traits including a cryptogam (spore) and spermatophyte (vascular bundle) form, which can be attributed to their specific evolutionary history. Among them, epiphytic ferns occupy unique habitats in forests, and their life-history strategies and evolutionary history exhibit close relationships with forest ecosystems. Most epiphytic ferns are capable of clonal growth. However, it is yet unclear how clonal life-history traits affect the adaptation of epiphytic ferns to forest canopies. Here, we review studies of rhizomatous clonal growth of epiphytic ferns, the relationship of fern clonality with ecological adaptation, the clonal forms of ferns, and the evolution of fern clonality. We then discuss the roles of fern clonality in the processes and functions of forest ecosystem and suggest future directions of how to combine fern ecology to global change studies.
\end{abstract}

Key words: pteridophytes; forest canopy; epiphytes; clonality; forest ecosystem; ecological functions

林冠是指森林地表以上全部树冠的集合, 包括 所有的叶片、枝条、小枝及附生植物(Nadkarni et al, 1996; Mendieta-Leiva \& Zotz, 2015)。林冠附生物在 维持森林生态系统物种多样性、水分和养分循环中
发挥着重要的作用, 并可为林冠中栖息的动物提供 重要资源(Basset et al, 2003; Lowman \& Schowalter, 2012)。尽管森林附生植物的生物量仅占森林地上部 分的 2\%-3\% (Nadkarni，1984), 但其对森林生态系

收稿日期: 2019-04-08; 接受日期: 2019-10-08

基金项目：云南省应用基础研究计划面上项目(2013FB076; 2019FB037)和国家自然科学基金(31300459; 31872685)

* 通讯作者 Author for correspondence. E-mail: luhuazheng@xtbg.org.cn 
统动态营养库的贡献却超过宿主植物叶片的生物 量(Chen et al, 2010)。过去人们对森林附生植物的关 注主要集中在风梨科和兰科等少数几个类群(Zotz \& Hietz, 2001), 虽然附生媭类植物也是森林附生植 物的一个重要类群, 但目前对附生蒝类植物的生理 生态学研究仍鲜有报道(Zhang et al, 2009a, b)。在世 界范围内, 蕨类植物的物种数只占附生维管植物的 9\%-11\% (Hsu \& Wolf, 2009), 且在古热带与新热带 地区一般也不高 $(\leq 25 \%-28 \%)$, 但该比例在中国云 南和台湾地区却高达 $52 \%-53 \%$ (徐海清和刘文耀, 2005; Hsu \& Wolf, 2009)。例如, 在云南哀牢山地区, 占附生维管植物生物量 $94 \%$ 的 7种植物中就有 6 种为 葓类; 频度大于 $10 \%$ 的 9 种优势种中, 蕨类植物占 8 种; 而对于附生维管植物的个体总数, 蕨类所占比 例达 $98 \%$ (马文章, 2009)。此外, 附生蓱类植物在山 地森林生态系统生物多样性维持和森林气候调节 方面具有重要的作用(Cummings et al, 2006), 如一 株鲜重约 $200 \mathrm{~kg}$ 的鸟巢硕(Asplenium nidus)能维持 约 41,000 个无脊椎动物所需的栖息空间, 其所维持 的无脊椎动物生物量也相当于该树冠内其他所有 枝叶的维持量(Ellwood \& Foster, 2004)。然而, 由于 气候变化与人类活动加剧, 附生蕨类植物的物种多 样性及丰富度极大降低(Benzing, 1998; Barthlott et $\mathrm{al}, 2001)$ 。为了更有效地保护附生蒝类植物, 继而维 持林冠中的生物多样性, 从生理生态学的角度对其 环境适应机制进行探讨至关重要。

近年来, 附生蕨类植物独特的生态适应策略不 断被发现(Schuettpelz \& Pryer, 2009)。在长期适应水 分胁迫、资源异质性强的林冠生境过程中, 附生䓲 类植物较地生蕨类进化出了多样化的性状并形成 多种生态策略, 如脱水耐受性、革质叶、厚角质层、 储水叶或肉质茎(Mehltreter et al, 2010)、收集叶 (humus-collectors or humus-collecting blades)、蚁栖 共生等(Dubuisson et al, 2009)。此外, 附生硕类植物 的水力解剖与代谢特征也使其能在附生生境中保 持叶片水分的相对稳定。相对于地生蒝类植物, 附 生蓱类植物在叶片水势较高时即关闭气孔(Zhang et al, 2009a), 且其水力导度更低, 而抗气穴化 (resistant to cavitation)能力更强(Watkins et al, 2010); 兼性附生蕨类附生个体的叶片比叶重较地生个体 大, 而叶脉密度、气孔密度、气孔大小等均较小 (Chen et al, 2019a)。在众多硕类植物中, 一些附生硕
类的根状茎具有克隆生长的习性(Mehltreter et al, 2010), 并且该特性使其能通过资源共享的方式缓 解林冠水分、养分、光照等环境异质性带来的压力 (Outridge \& Hutchinson 1991; Klimeš et al, 1997; Carlquist \& Schneider, 2001; Lu et al, 2015)。尽管研 究克隆性在蕨类生态适应与功能中的作用方兴未 艾, 但不少学者已经在关注偋类克隆性的生态意义 与功能(Du et al, 2010; Guo et al, 2011; Lu et al, 2015; Medeiros et al, 2018; de Oliveira Xavier et al, 2019)。 因此, 本文从附生蕨类植物的根状茎克隆生长、克 隆性与生态适应性、不同克隆生长方式与进化等方 面进行综述, 并展望了蓱类植物克隆性在森林生态 系统过程与功能中的作用, 以及今后如何将䓲类植 物生态学研究与气候变化、土地利用变化等全球变 化的主流方向进行结合。

\section{附生葓类植物的克隆生长与克隆整合}

克隆生长是指在自然条件下, 生物自发地通过 营养方式形成遗传上相同, 且具有潜在独立性的新 个体或分株的能力或过程(董鸣和于飞海, 2007)。在 气候变化背景下, 有机体从异质或胁迫的环境中获 取资源并分配到不同构件的能力对其生存与繁殖 能力至关重要(Robinson \& Beckerman, 2013)。由于 光、水分和养分等资源在自然界中呈异质性分布, 增加了植物获取资源的难度, 使其在长期进化过程 中形成各种适应性对策(董鸣, 2011)。对于克隆植物, 与基株相连的分株对异质性资源作出的响应与非 克隆植物的各构件相类似(He et al, 2011)。克隆植物 通过克隆分株的选择性放置实现“受食行为” (Cain, 1994; 董鸣，2011)，并通过分株间资源与信息的分 配和共享以实现克隆内的生理整合(Alpert, 1991; Yu et al, 2004; Xu et al, 2012), 从而达到对异质生境 的适应(Song et al, 2013)。所谓克隆内生理整合(即 克隆整合)是指克隆内分株间的物质和/或信号相互 传输, 并改变了相连分株的行为(董鸣, 2011)。大多 数研究者认为克隆生长能通过克隆整合的方式增 强有机体在资源异质生境下的适合度(Hartnett \& Bazzaz, 1983), 但也有研究发现维持克隆分株间相 连的间隔子也需要一定的内在成本 (initial costs) (Slade \& Hutchings, 1987)。因此, 从长远来看, 克隆 植物必须在克隆整合与间隔子维持之间进行“权衡” (trade-off) (Slade \& Hutchings, 1987), 分株之间断开 
与否取决于克隆生长对环境异质性响应的结果(董 鸣, 2011)。

相对于林下地面，林冠生境的光照、水分和养 分等的异质性程度更高, 这对附生蓱类植物的存活 与生长是最大的一个挑战(卢华正, 2017; Chen et al, 2019b)。然而, 多数附生䓲类植物具有克隆生长的 习性, 且以根状茎克隆生长(根茎型)为主(董鸣和于 飞海, 2007; 卢华正, 2017)。与地生硕类不同, 附生 偋类植物的根状茎除具有克隆繁殖的作用之外, 还 兼具储存水分和营养(Andrade \& Nobel, 1997)、攀附 针定的重要功能(Tsutsumi \& Kato, 2006)。由此推断, 对于根茎型附生蒝类植物, 即使分株间克隆整合的 收益为零, 为了储存和针定的作用, 根状茎断开与 否的“权衡”势必向“相连”倾斜。在此情况下, 在克 隆整合与间隔子维持的“权衡”中, 根状茎对克隆整 合、存储与错定三者的贡献如何? 对此进行深入探 讨的首要问题是需要弄清根茎型附生蕨类是否存 在广泛的克隆整合作用, 以及克隆整合格局与收益 如何。然而, 目前关于这方面的研究主要集中于被 子植物(Abrahamson et al, 1991; Song et al, 2013), 而对硕类植物克隆整合及其生态功能的分析仅有 少数几例(Outridge \& Hutchinson, 1991; Du et al 2010; Guo et al, 2011), 与此相关的工作仍需不断加 强(Lu et al, 2015, 2016; Zhang et al, 2019b)。

\section{2 附生屏类植物的根状茎克隆性}

\section{1 附生斴类克隆性分析一以云南热带亚热带 森林为例}

在我国, 大多数偋类植物种类分布在长江流域 以南的地区。其中, 仅云南省就有 1,500 多种, 涵盖 了十分丰富的附生植物种类, 是硕类植物的地理分 布中心(陆树刚, 2007; 马文章, 2009)。已有研究表 明, 西双版纳附生植物属的分布具有明显的热带亚 洲性质, 该地区的附生偋类植物在附生维管植物中 是仅次于兰科的第二大类群(吴毅等, 2016)。此外, 位于云南省中部的哀牢山是古热带植物区系成分 和东亚植物区系成分交错分布地带, 是全国硕类植 物多样性最为丰富的地区之一, 已记录到的附生䓲 类与石松类植物有 93 种(徐成东和陆树刚, 2006; 徐 成东等, 2011; 汤丹丹等, 2018)。独特的地理位置和 丰富的物种数量使二者成为研究热带和亚热带附 生烣类植物的生态特征、物种多样性及其生态效应
的理想之地, 相关的研究也得以广泛而深入地开展 (徐成东和陆树刚, 2006; 吴毅等, 2016)。

为分析云南热带和亚热带森林中具克隆生长 习性的附生硕类植物的多样性, 本文对哀牢山亚热 带常绿润叶林和西双版纳热带森林中附生植物的 相关研究资料进行了汇编, 并结合野外调查, 获取 了附生蓱类植物物种的相关信息。以此为基础, 在 中国植物志网站上对每个物种逐一进行查询, 根据 野外观察记录与网站对根状茎等性状的描述, 进一 步区分蕨类植物狍子体的克隆性与非克隆性。结果 表明: 汇编的哀牢山亚热带森林硕类植物共计 170 种(包括石附生) (附录1), 其中 124 种具横走茎, 即 通过根状茎克隆生长的蕨类物种数比例达 $73 \%$; 在 西双版纳热带森林中, 所汇编的147种蕨类植物中 共有116种具横走茎, 即通过根状茎克隆生长的䓲 类物种数所占比例达 $79 \%$ (附录 2 )。此外, 在哀牢山 徐家坝地区亚热带常绿阔叶林内调查到的34种附 生鄀类植物中, 共 31 种具有横走根状茎、 1 种的叶轴 基部具有克隆生长能力, 具有克隆性生长的物种数占 哀牢山所有附生葓类植物物种数的比例达 $94 \%$ (附 录1); 在西双版纳热带森林中共调查和记录了 41 种 附生蕨类植物, 其中 35 种具有横走根状茎, 2 种具有 匍匐茎, 1 种的叶尖具有克隆生长能力, 克隆性䓲类 物种数所占比例达 $93 \%$ (附录 2 )。因此, 本文对于附 生蓱类植物克隆性的探讨主要以根状茎克隆为主。

\section{2 根茎型附生築类是否存在克隆整合}

相对于地生䓲类植物, 附生䕬类植物通常具有 更厚的叶片和更小的比叶面积, 这意味着它们的叶 片构建成本较高, 而较低的光合速率使它们需要更 长的时间来偿还初始的叶片构建成本和满足物质 消耗的需要(宋娟等, 2013; Zhu et al, 2016)。这些特 征导致附生䓲类植物对环境变化和生境异质化的 适应能力较弱, 面临着极大的生存压力(宋娟等, 2013)。然而, 对于根茎型附生硕类植物, 仍需要开 展相关的研究以验证在其适应异质生境过程中是 否存在克隆整合。Du等(2010)对林下自然种群地生 莿里白(Diplopterygium glaucum)的自然种群进行了 切断根状茎的小区与单株处理, 发现切断根状茎影 响分株的存活和植株生长, 但并不显著。其原因可 能是克隆整合在有些物种中作用的程度较小, 且分 株响应的差异不完全是个体大小的差异所导致。 Guo等(2011)进一步说明在光照、养分等资源异质的 
生境中, 横走的根状茎对偋类植物克隆分株的存 活、资源分配及共享具有重要作用, 而且这种整合 取决于资源异质性的大小(Du et al, 2010; Guo et al, 2011)。进而通过野外原位实验, 卢华正等对哀牢山 林冠7种优势根状茎克隆附生蒝类进行切断处理, 结果表明尽管存在一定的物种特异性差异, 但大多 数附生蕨类植物的存活与生长依赖于克隆整合(卢 华正, 2017; Lu et al, 2020)。同时Zhang等(2019b)对 附生硕类长叶实葓(Bolbitis heteroclita)进行切断处 理, 发现切断根状茎影响分株存活且对叶片生长有 影响, 切断明显降低了子株的存活率与生长。因此, 在自然资源时空异质性强、水分养分胁迫频繁的林 冠生境中, 附生蕨类植物横走的根状茎应该发挥着 克隆整合的重要作用。

\section{3 附生蕨类植物的克隆性与生态适应性}

\section{1 克隆附生渃类植物功能性状的可塑性}

林冠的遮挡与蒸腾作用对亚热带常绿阔叶林 的林下微气候具有强烈的影响。Chen等(2019b)利用 小气候观测系统(Hobo U30, Onset Computer Corporation)在附生蕨类植物生长期内进行短期的观测发 现，尽管林冠与林下腐殖质的日均温无显著差异， 但白天林冠气温显著高于林地而空气相对湿度则 相反。此外, 林冠叶片湿度显著低于林地, 但光合 有效辐射正好相反, 即林冠显著高于林地(Chen et al, 2019a, b)。在哀牢山湿性常绿阔叶林中, 对兼性 附生根状茎型克隆偋类植物大果假瘤䓲(Selliguea griffithiana)功能性状的研究表明: 林冠附生分株的 叶长、柄长、间隔子长度、气孔密度、叶脉密度、 $F \mathrm{v} / F \mathrm{~m}$ 、相对叶绿素含量、单株生物量均小于林下 地生分株; 附生种群拥有小而密的分株, 而地生种 群的分株个体更大, 且分布更为稀疏; 光响应曲线 表明, 大果假瘤烣地生分株的光合能力大于附生分 株, 而失水曲线表明附生分株的保水能力比地生分 株强(Chen et al, 2019b)。由此可见, 克隆兼性附生 烣类植物能通过功能性状的调节与表型可塑性以 适应所处的环境, 即附生分株通过提高叶片保水能 力以缓解林冠水分缺乏带来的负面影响, 而地生分 株则通过提高光照的利用效率以适应林下的低光 环境(Lu et al, 2015; Chen et al, 2019b)。

\section{2 附生屏类植物的克隆整合作用及其适应调节} 兼性附生植物可同时占据森林林冠和林地两
种生境(Lowman et al, 2013)。相对于林下地生生境, 由于受降雨、刮风和断枝等因素影响, 林冠附生生 境的水分和养分存储能力较弱, 其物理稳定性更差, 且林冠生境中水分和养分有效性的生境异质性更 强、可预测性更低(Lowman \& Schowalter, 2012)。 因此, 与地生蕨类相比, 附生蒝类植物的生境条件 更为严酷 (Endler, 1993; Lowman \& Schowalter, 2012)。基于该环境背景，Lu等(2015)通过在山地湿 性常绿阔叶林中对大果假瘤蒝的实验中发现, 在具 有季节性干旱的山地森林中, 克隆整合作用对于附 生蒝类植物在干季的存活与生长具有关键的作用, 尤其是在旱季水分极端亏缺的林冠生境中, 克隆整 合对于兼性附生蓱类的附生分株至关重要。克隆整 合作用对兼性附生植物附生分株与地生分株的影 响具有差异性, 可能预示着自然选择使其不同基因 型之间产生了适应性分化(Lu et al, 2015)。

研究者通过进一步的实验, 从大果假瘤硕单个 物种扩展到哀牢山 8 种优势附生蓱类, 发现它们在 形态、生理与物候学特征上有很大差异(徐海清和刘 文耀, 2005)。Lu等(2016)通过开展野外原位实验, 更 进一步明确根状茎断开对附生蒝类植物个体实验 中分株的存活能力和群体实验中分株存活数均具 有显著的负面影响; 尽管附生植物种间具有显著不 同的性状特征，但根状茎断开对不同物种分株的存 活及生物量的影响较为一致, 意味着这种负面影响 并不因物种而异。作为自然选择的结果, 克隆整合 在许多生态系统的克隆植物的生存适应过程中得 到了大量的实验证实(Alpert, 1991; He et al, 2011)。 研究者认为, 尽管附生植物适应林冠生境的生态策 略在物种间有可能不同, 但系列研究表明, 通过克 隆整合而实现的资源共享是克隆附生植物的又一 种重要策略(Lu et al, 2016)。

\section{3 附生硕类植物的克隆方式与生态适应性}

在自然条件下, 蓱类植物狍子体克隆繁殖方式 较为多样(Mehltreter et al, 2010), 主要有根状茎型、 珠芽型、叶尖型、根源型等。根状茎型克隆生长是 偋类植物最常见的繁殖方式, 根状茎横走尤其是根 状茎长而横走的蕨类物种均具有克隆繁殖能力, 如 伏石蕨(Lemmaphyllum microphyllum)、贴生石韦 (Pyrrosia adnascens)、圆盖阴石䕬(Humata tyermanii) 等。珠芽型克隆生长的有胎生狗脊 (Woodwardia orientalis)、胎生铁角硕(Asplenium yoshinagae)、芽 
狍三叉硕(Tectaria fauriei)等。叶尖型克隆生长的蒝 类植物有鞭叶铁线蒝(Adiantum caudatum)、单叶鞭 叶蒴(Cyrtomidictyum basipinnatum)、鞭叶耳硕(Polystichum craspedosorum)、过山蒝(Camptosorus sibiricus)等。根源型克隆生长如鹿角蕨(Platycerium wallichii)等(李莉和严岳鸿, 2014)。此外, 个别蓱类 植物具有多种克隆生长方式, 如长叶实蒝和中华刺 䓲(Bolbitis sinensis) 兼具叶尖克隆生长和根状茎克 隆生长的习性(Zhang et al, 2019b)。

偋类植物克隆生长方式的多样化意味着其生 长习性及适应策略的不同, 而克隆整合在其中的作 用是否一致仍不明确。在此基础上, Song等(2013) 利用meta分析比较了种子植物的克隆整合作用, 发 现克隆整合在根状茎型与匍匐茎型之间差异不显 著。对于研究克隆整合作用在不同克隆生长方式间 如何变化, 一个行之有效的方法是比较克隆整合在 同一物种不同克隆方式间的差异。为此, Zhang等 (2019b) 以热带雨林半附生植物长叶实蒝(Bolbitis heteroclita)为对象, 比较了不同克隆方式(根状茎型 与叶尖型克隆)的分株间克隆整合的作用, 结果发 现不同克隆方式的分株对克隆整合的依赖程度有 较大差别, 并且以根茎型克隆整合收益更高, 这与 维管束面积及其所占横切面的比例有关。根茎型克 隆生长与叶尖克隆生长表明了长叶实偋对热带雨 林林下或树干基部的低光环境以及多物种竞争生 境中的不同适应策略。根茎型克隆生长方式有利于 附生蒴类植物在局域范围内建立较大的分株种群, 从而防止其他物种的侵入, 这类似于偏密集型克隆 生长策略; 而叶尖型克隆生长的方式使植株能更有 效地获取光照资源, 且在分株的放置上具有更多的 选择性, 从而逃避不利生境, 这属于偏游击型克隆 生长策略; 蕨类的孢子远距离繁殖至叶尖型繁殖再 至根状茎型繁殖可能构成一个由远及近的距离繁 殖谱(卢华正, 2017; Zhang et al, 2019b)。兼具不同的 克隆生长方式使长叶实藓形成了独特的生态适应 策略(如资源共享、克隆分工、风险分摊等), 这也可 能是其成为热带雨林林下最优势的偋类植物的潜 在机制。

\section{4 附生烣类的克隆性与群落构建}

作为林冠生物多样性的重要组分, 附生植物在 森林生态系统生物多样性维持、物质循环等方面起 着重要作用。在世界范围内, 附生维管植物物种数
高达27,000余种(Zotz, 2013); 在亚热带地区，其累 积的生物量也较高, 如云南省哀牢山常绿阔叶林内 附生物的生物量达 $10.68 \mathrm{t} / \mathrm{ha}^{1}$ 。基于许多附生植物 和大多数优势物种具有克隆性的事实(Jackson et al, 1985; Robinson \& Miller, 2013), Lu等 $(2015,2016)$ 通 过野外处理实验探讨了克隆整合是否可作为一种 种内促进作用, 在附生植物的存活与生长过程中发 挥重要的生态功能。在一个稳定的森林生态系统中, 生物物种之间存在促进(正)和竞争(负)的相互作用 并形成一个动态平衡(张炜平等, 2013)。根据胁迫梯 度假说(Bertness \& Callaway, 1994), 随着环境胁迫 度的增加, 生物间正相互作用逐渐加强(Chu et al, 2008; He et al, 2013)。如在极地苔原、高山、水域 等环境中, 生物间通常表现为促进作用(Callaway et al, 2002; Cavieres et al, 2014)。据此，在水分极度缺 乏和环境异质性强的林冠生境中, 附生植物群落中 的种间关系是否倾向于相互促进?

为探明该问题， $\mathrm{Lu}$ 等(2020)通过采用阻止克隆 整合与移除非维管植物的方法, 比较了处理前后附 生蒝类植物的生长情况, 结果表明附生蒝类的生长 对二者及其交互作用具有较强的依赖性。然而, 这 种促进关系背后依然隐藏着诸多科学问题。比如, 非维管植物对附生维管植物的促进源于直接的资 源富集与生境改良, 还是多物种竞争产生的间接促 进作用? 附生维管植物之间的相互作用如何? 鉴于 附生植物在生物多样性维持中的重要地位, 以及大 多数优势种具有克隆性的事实, 关于植物的克隆性 与林冠群落构建和物种共存机制的关系, 及其对共 存物种可能产生的级联效应等方面亟待深入研究 (Lu et al, 2016, 2020)。

\section{附生蕨类植物的克隆性与进化}

\section{1 蕨类克隆性的演化历史}

随着白严纪时期有花植物的逐渐兴起, 其他维 管植物支系的多数物种几近灭绝。被子植物约占维 管植物物种数的 $96 \%$, 其他的 12 个维管植物支系 (石 松类、水非类、卷柏类、松叶蒴类、箭蒝类、莲座 偋类、楔叶类、薄囊茨类、苏铁类、银杏类、松柏 类、买麻藤类)种数均不多。然而, 薄囊偋类支系是 唯一的例外, 现存有 9,000 多个种, 是其余 11 个隐花

(1) 徐海清 (2005) 哀牢山山地湿性常绿阔叶林附生物的组成与分布. 硕士学位论文, 中国科学院西双版纳热带植物园, 云南预腊. 
植物支系物种数总和的近 4 倍。根据化石记录与分 子生物学研究, 薄囊藓类发生了 4 次大的辐射扩散, 现存的蓱类物种主要是在被子植物繁盛之后第三、 四次分化形成的(张宪春, 2012)。第三次从白亚纪开 始, 主要形成林下偋类; 第四次新生代的快速演化 使附生蒝类得以繁荣, 尤其是在由被子植物构成的 热带雨林中占据了林冠生态位(Schuettpelz \& Pryer, 2009; 张宪春, 2012)。由此可见, 现存蒝类的形成及 其生态适应性与森林生态系统密不可分; 其分化并 非是面对被子植物兴起的被动妥协, 而是利用被子 植物创造的林下生态位, 并逐渐发展了附生其上的 能力(Smith et al, 2006; Schuettpelz \& Pryer, 2009)。 然而, 我们对蕨类植物如何适应森林环境特别是附 生生境的理解, 以及对附生进化机制(evolution of epiphytism)的认识仍然十分有限(Tsutsumi \& Kato, 2006)。

关于附生䓲类的进化途径主要有两种不同的 观点: 一是阳生蒝类植物先适应林下荫生生境, 然 后逐渐分化扩散到林冠附生生境; 二是阳生硕类不 经过林下生境, 直接进化到林冠生境(Mehltreter et al, 2010)。Chen等(2019a)以亚热带常绿阔叶林中两 种优势附生蒝类植物棕鳞瓦韦(Lepisorus scolopendrium) 和二色瓦韦(L. bicolor)为研究对象, 调查了 二者在原生林及两类处于不同退化阶段的次生林 中的垂直空间分布格局, 并比较了它们在这 3 种森 林类型中的功能性状。结果表明, 两种专性附生䓲 类植物在次生林中转变为兼性, 多分布于树干基部 和林地土壤, 在森林退化过程中, 它们通过在种内 水平上调整功能性状以实现这种转变, 并通过克隆 生长促进了根状茎延伸, 以找到最佳栖息生境。综 上, 结合蒝类植物的进化史, 附生蓱类的根茎型克隆 可能与附生关系的进化相关, 而且有可能先经过林 下再进化到林冠, 因为根茎型克隆有利于分株个体 的移动与攀援。然而, 这一推测有待于进一步验证。

植物进化出了可调控多种生长策略的不同发 育途径, 从而可以通过不同的生长方式实现对环境 资源的有效获取和损伤后的生长修复, 有时甚至可 以赋予植物 “智能” (Trewavas, 2005)。其中, 植物最 具适应性优势的生长方式为重复性(reiteration), 即 在植物体上重复生产相同生长构件的能力 (Hallé, 1999; Tomescu et al, 2008)。重复性生长(reiterative growth) 是种子植物常见的生长与适应策略, 尽管目
前对硕类植物的重复性生长研究较少, 但已有研究 表明古硕类植物Kaplanopteris clavata具有这种复杂 的根状茎生长适应结构(Tomescu et al, 2008)。此外, 根茎型克隆可能是蕨类植物最早的克隆生长方式 (Tomescu et al, 2008; Matsunaga \& Tomescu, 2017)。 严格意义上, 目前仅有少数几种古代维管植物的形 态特征、生长习性及生活史等得到过详细而完整的 描述。如对于最早的一种古石松类植物 Sengelia radicans, 研究者推断其繁殖方式主要是根状茎克 隆，而有性繁殖极其罕见(Matsunaga \& Tomescu, 2017)。可见, 克隆性可能是蒝类植物与生俱来的本 质属性之一。然而, 在以恐龙为霸主的蒝类繁盛时 期, 蕨类的克隆生长显然受到过抑制, 因此克隆性 在硕类的进化过程中可能具有间断性或是多次进 化。由于现代蓱类基本上是被子植物时代之后的进 化产物, 硕类中的进化类群(如附生蒝类植物中的 进化种)与被子植物中的进化类群(如兰科)在进化 意义与生态策略上应该较为相似, 如CAM (Crassulacean Acid Metabolism)途径和克隆生长等。由此可 知, 根状茎克隆作为早期蒝类植物中普遍存在的特 征, 在䓲类植物适应环境的过程中具有重要意义, 这也为偋类植物进入林冠生境奠定了基础。

\section{2 粕类克隆性的形成过程与可能机制}

大部分石松类与䕬类植物的生活史(图1)表明, 其克隆性体现在以下两个方面: (1)克隆生长与克隆 生殖(Pickett, 1931); (2)配子体克隆性与孢子体克隆 性(Priestley \& Swingle, 1929; Kuehnert, 1967; Mehltreter et al, 2010)。烣类植物的克隆生殖包括无配子 生殖、无孢子生殖和孤雌生殖等。如日本铁角蕨(Asplenium niponicum)、掌叶铁线硕(Adiantum pedatum) 等。克隆生长无论在植物界还是在森林生态系统中 都更为普遍(董鸣和于飞海, 2007)。一些硕类物种的 配子体能产生营养芽或芽孢(gemmae), 且可与母体 分离及独立生长, 从而形成巨大的配子体种群并完 全独立于附近的狍子体(Farrar et al, 2008)。对于配 子体种群, Watkins等(2007)发现地生葓类植物的物 种多样性与丰度(配子体)随着光照与干扰的增强而 升高, 但附生蕨类配子体由于受到干扰的负面影响 而与光照没有显著相关性。

在自然条件下，蓱类植物孢子体具有多种克隆 繁殖方式(图1), 且其克隆分株与新生芽的分生位置 也比种子植物更加多样化(Richards et al，1983; 

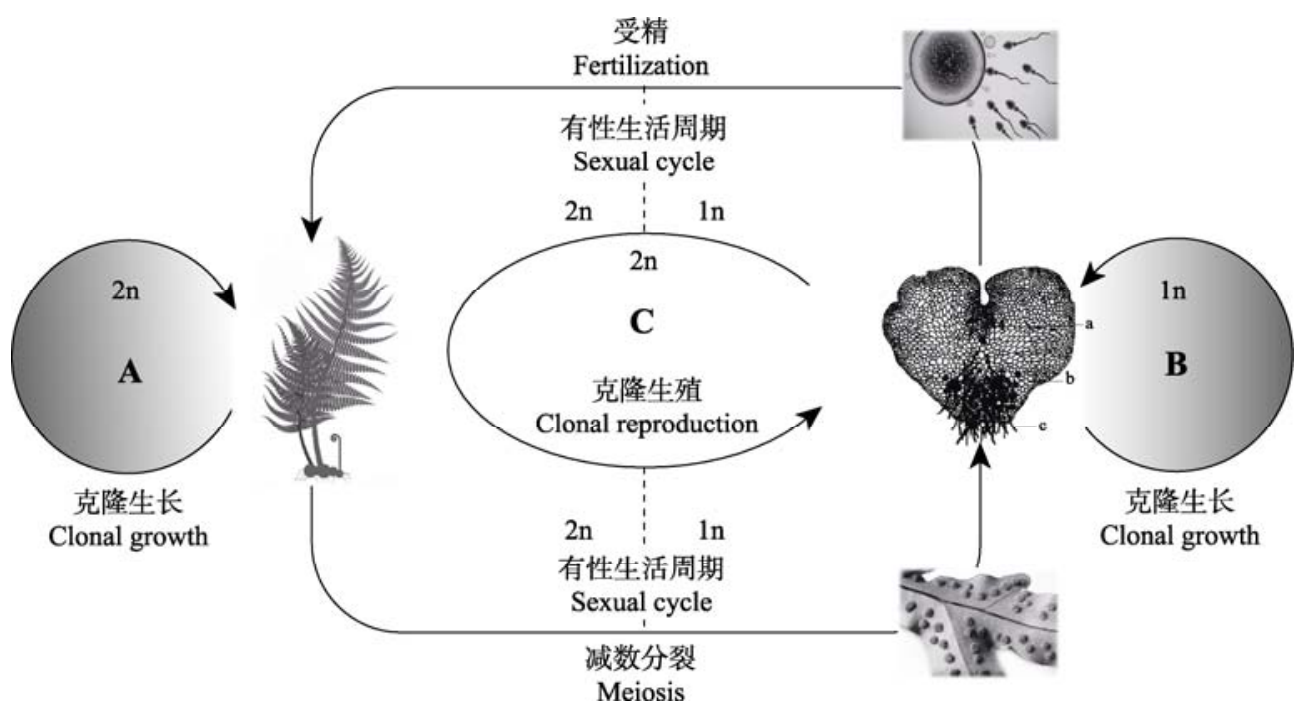

图1 濒类植物生活史特征与克隆性。循环A示孢子体克隆性, 循环B示配子体克隆性, 循环C示单性生殖; ABC颜色深浅顺序 示自然状况下发生频率由高到低(改自Mehltreter et al, 2010)。

Fig. 1 Life history and clonality of ferns. Circle A for clonal growth of sporophytes, circle B for clonal growth of gametophytes, circle $\mathrm{C}$ for clonal reproduction; colors from dark A to B to light $\mathrm{C}$ showed occurrence frequency from high to low in nature (Revised from Mehltreter et al, 2010).

Mehltreter et al, 2010; Fujinuma et al, 2019)。Bower (1923) 归纳了偋类植物 5 类主要的分枝结构: 权状 分枝型(dichotomous)、叶腋分枝型(axillary)、叶腋 外分枝型(extra-axillary)、羽片不定分枝型(adventitious on leaf laminae)和根上不定分枝型(adventitious on roots)。这与种子植物中经典的叶腋分枝模式, 即 一个叶片的叶腋内包含着一个或几个侧芽 (lateral bud) (Goebel, 1905)形成了鲜明的对比。此外, 偋类 植物孢子体不但具有多种新芽分枝方式, 而且有些 䒴类植物叶片在发育初期还具有相对不确定性的 特点。一些研究由此认为, 䓲类植物的叶芽与根等 形成组织的确定性(organ determination)具有很大的 灵活性与可变性(Priestley \& Swingle, 1929; Kuehnert, 1967)。因此, 偋类植物孢子体新生分株的形成 具有一定的随机性, 这可能使得在一定的环境条件 下, 蕨类植物可以通过改变茎尖或根尖原基(primordia)的发育过程从而选择不同的无性繁殖方式 (Richards et al, 1983) 以提高其适合度。然而, 这种形 成组织的可变性与随机性具有怎样的进化意义? 是否与克隆生长的双重表型可塑性和克隆植物的 受食行为具有内在的关系? 这些问题的解答还需 要开展大量的研究。

\section{3 颣类对低光的适应及其附生进化驱动}

尽管克隆蒝类通常是频繁干扰生境中草本层 的优势种，但de Oliveira Xavier等(2019)对一种热带 蒝类植物Pteridium arachnoideum的研究表明，该物 种的死亡率随着林冠郁闭度的增加而急剧增加。由 于林冠的遮蔽作用, 林内光照条件较差且在林冠中 的不同位置有较大的波动, 林下濒类植物进化形成 了一套特异的光感受器, 即一个红光一远红光受体 色素与向光素的镶嵌体, 这个镶嵌的光感受器在蒝 类植物分化与扩散到低光环境中具有重要的作用 (Kawai et al, 2003)。蕨类植物对林下低光环境的适 应使其得以繁荣，并且通过繁殖体的传播等方式进 入林冠。此外, 蕨类植物进化出低光生存能力后, 在被子植物与裸子植物的竞争中发挥着生态过滤 器(ecological filter)的作用, 调节这两者竞争的过程 与结局(Coomes et al, 2005)。

通过探讨林下蓱类生态过滤能力的可能机制, 发现蕨类植物的克隆性在森林群落构建、演替以及 生态系统过程与功能中发挥着重要的作用(Coomes et al, 2005; Aikens et al, 2007; Mehltreter et al, 2010)。 林下硕类植物的相关研究表明, 物种间存在低光耐 受度与林地光照条件下的最大生长之间的权衡 (George \& Bazzaz, 1999)。正是由于这种光照-生长 的权衡与低光胁迫, 加之林下生境的种间竞争作用, 一些蒝类植物在森林生态系统提供的多样化的生 境中逐渐进化出附生生活型(Dubuisson et al, 2009), 
为被子植物兴起后偋类植物的第四次大规模演化 (附生萨类的演化)提供了条件与机遇(Schneider et al, 2004; Schuettpelz \& Pryer, 2009)。而石松类与䓲类植 物的克隆性为附生生活型的形成与实现提供了可 能(Tomescu et al, 2008; Matsunaga \& Tomescu, 2017; Chen et al, 2019a)。

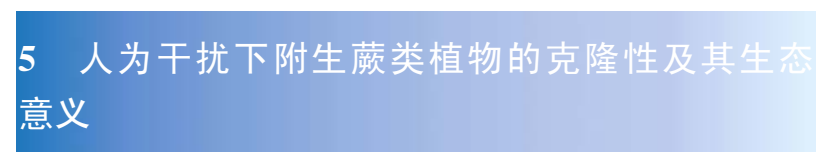

土地利用变化与人为干扰是生态系统所面临 的全球性问题。由于附生植物需要宿主植物作为结 构性支撑, 森林片断化与干扰(如非木质产品采收) 所导致的树木死亡、倒伏、断枝等, 都将直接改变 林冠生境状况并影响附生植物的命运。微生境通常 充当有机体的结构性载体, 它可以是物理因素形成 的结构, 如裂缝、土坑, 也可以是生物因素形成的 载体, 如珊瑚骨架、倒木等(Crowe，1996)。由于环 境条件、林冠结构、资源分布等在林冠的多变性, 使 得干扰与微生境片断化在林冠环境中普遍存在 (Hietz, 1997)。如前所述, 由于干旱胁迫、环境波动 与资源异质性, 大多数附生植物形成多样化的生理 生态适应策略(Zotz \& Winter, 1994), 如克隆生长习 性与克隆整合作用(Lu et al, 2016)。然而, 在气候变 化与人类活动加剧的背景下, 自然与人为干扰导致 的微生境片断化对附生蒝类植物的影响如何? 克 隆分株的生长发育如何响应这种生境片断化及其 导致的克隆片段化? Watkins等(2007)通过对附生和 地生硕类植物配子体生态及种群动态的研究表明, 附生和地生烣类植物配子体的存活和生长与其受 到的干扰和竞争相关。蒝类植物经过了相对脆弱的 配子体阶段之后, 其孢子体在自然状况下常常以克 隆繁殖的方式进行更新。卢华正(2017)的研究表明: (1)分株相对年龄和克隆片段大小对克隆烣类植物 的存活与生长具有显著影响, 而且两个因子之间存 在显著的交互作用, 但二者对分株形态与生理参数 没有显著影响; (2)较大克隆片段中单位分株的生物 量大于较小克隆片段, 但克隆片段中成熟分株的生 物量小于未成熟的刚伸展的年幼分株; (3)随着附生 蕨类植物分株年龄的增长, 其对克隆整合的依赖性 降低, 而随着克隆基株的片段化的加剧, 其对附生 烣类生长的负面影响增加。
然而，附生葓类克隆片段的最小安全存活单位 如何确定? 克隆性与干扰(如取食)引起的叶片损伤 或根系剥离关系如何? 克隆性在蒴类响应人类活 动干扰中的作用如何? 这些问题仍有待于进一步 研究。

\section{展望}

许多植物同时具有克隆生长与有性繁殖, 这两 种繁殖方式间的平衡在不同物种间以及同一物种 的不同种群间变化很大(张玉芬和张大勇, 2016)。克 隆植物的生活史策略中的无性与有性繁殖对策相 互作用影响了克隆植物对异质环境的适应与进化。 蒝类植物配子体与孢子体世代出现的克隆生长也 是与有性繁殖相辅相成、密不可分的(图1)。在茨类 植物漫长的进化历史中, 孢子的远距离传播与有性 繁殖以及孢子体在局域范围内的克隆生长(以及不 同克隆方式可能构成一个由远及近的繁殖谱)使硕 类植物生生不息, 从而在隐花维管植物的繁衍进化 过程中一枝独秀 (Schuettpelz \& Pryer, 2009; Mehltreter et al, 2010; Zhang et al, 2019b)。附生蓱类的大 规模扩散分化即是蒝类植物历史上四次大规模演 化至今的最新阶段(张宪春, 2012), 这预示着林冠生 境是蓱类植物发展演化的主要方向之一。因此, 在 时间尺度上, 无论是小尺度的生态适应与生活史策 略, 还是大尺度的进化与发展, 现存蕨类的生态与 进化都与森林生态系统相关联, 而茨类植物普遍存 在的克隆性是否以及如何在森林生态系统结构、过 程与功能中发挥作用, 还有待深入研究(卢华正, 2017)。

林冠及其组分位于森林与大气层相互作用的 关键交互界面，对环境变化极为敏感，具有生物指 示作用(Ozanne et al, 2003), 能为全球变化研究提供 早期识别参考和预警(Lowman et al, 2013); 加之偋 类植物既不依赖传粉者也不需要种子散布者, 故其 生活史的任何阶段都与非生物环境、气候、生长基 质等的关系更加紧密(Barrington, 1993; Mehltreter et $\mathrm{al}, 2010)$ 。因此, 在全球变化与人类活动加剧的背景 下, 如何结合克隆生态学, 将偋类植物生态学与气 候变化、生物多样性丧失、土地利用变化等全球变 化主流研究相结合(Outridge \& Hutchinson, 1991; Flinn et al, 2014; Zhang et al, 2019a), 是未来颇具前 
景的科学命题, 也是未来蕨类生态学研究的主要方 向之一。

\section{参考文献}

Abrahamson WG, Anderson SS, McCrea KD (1991) Clonal integration: Nutrient sharing between sister ramets of Solidago altissima (Compositae). American Journal of Botany, 78, 1508-1514.

Aikens ML, Ellum D, McKenna JJ, Kelty MJ, Ashton MS (2007) The effects of disturbance intensity on temporal and spatial patterns of herb colonization in a southern New England mixed-oak forest. Forest Ecology and Management, 252, 144-158.

Alpert P (1991) Nitrogen sharing among ramets increases clonal growth in Fragaria chiloensis. Ecology, 72, 69-80.

Andrade JL, Nobel PS (1997) Microhabitats and water relations of epiphytic cacti and ferns in a lowland neotropical forest. Biotropica, 29, 261-270.

Barrington DS (1993) Ecological and historical factors in fern biogeography. Journal of Biogeography, 20, 275-279.

Barthlott W, Schmit-Neuerburg V, Nieder J, Engwald S (2001) Diversity and abundance of vascular epiphytes: A comparison of secondary vegetation and primary montane rain forest in the Venezuelan Andes. Plant Ecology, 152, 145-156.

Basset Y, Horlyck V, Wright SJ (2003) Forest canopies and their importance. In: Studying Forest Canopies from Above: The International Canopy Crane Network (eds Basset Y, Horlyck V, Wright SJ), pp. 27-34. Smithsonian Tropical Research Instritute and UNEP, Panama.

Benzing DH (1998) Vulnerabilities of tropical forests to climate change: The significance of resident epiphytes. Climatic Change, 39, 519-540.

Bertness MD, Callaway R (1994) Positive interactions in communities. Trends in Ecology \& Evolution, 9, 191-193.

Bower FO (1923) The Ferns (Filicales), Vol. 1. Cambridge University Press, Cambridge.

Cain ML (1994) Consequences of foraging in clonal plant species. Ecology, 75, 933-944.

Callaway RM, Brooker RW, Choler P, Kikvidze Z, Lortie CJ, Michalet R, Paolini L, Pugnaire FI, Newingham B, Aschehoug ET, Armas C, Kikodze D, Cook BJ (2002) Positive interactions among alpine plants increase with stress. Nature, $417,844-848$.

Carlquist S, Schneider EL (2001) Vessels in ferns: Structural, ecological, and evolutionary significance. American Journal of Botany, 88, 1-13.

Cavieres LA, Brooker RW, Butterfield BJ, Cook BJ, Kikvidze Z, Lortie CJ, Michalet R, Pugnaire FI, Schöb C, Xiao S, Anthelme F, Björk RG, Dickinson KJM, Cranston BH, Gavilán R, Gutiérrez-Girón A, Kanka R, Maalouf JP, Mark AF, Noroozi J, Parajuli R, Phoenix GK, Reid AM, Ridenour WM, Rixen C, Wipf S, Zhao L, Escudero A, Zaitchik BF,
Lingua E, Aschehoug ET, Callaway RM (2014) Facilitative plant interactions and climate simultaneously drive alpine plant diversity. Ecology Letters, 17, 193-202.

Chen L, Liu WY, Wang GS (2010) Estimation of epiphytic biomass and nutrient pools in the subtropical montane cloud forest in the Ailao Mountains, south-western China. Ecological Research, 25, 315-325.

Chen Q, Lu HZ, Liu WY, Wu Y, Song L, Li S (2019a) Obligate to facultative shift of two epiphytic Lepisorus species during subtropical forest degradation: Insights from functional traits. Forest Ecology and Management, 435, 66-76.

Chen Q, Sun JQ, Song L, Liu WY, Yu FH, Li S, Gong HD, Lu HZ (2019b) Trait acclimation of the clonal fern Selliguea griffithiana to forest epiphytic and terrestrial habitats. Ecological Research, 34, 406-411.

Chu CJ, Maestre FT, Xiao S, Weiner J, Wang YS, Duan ZH, Wang G (2008) Balance between facilitation and resource competition determines biomass-density relationships in plant populations. Ecology Letters, 11, 1189-1197.

Coomes DA, Allen RB, Bentley WA, Burrows LE, Canham CD, Fagan L, Forsyth DM, Gaxiola-Alcantar A, Parfitt RL, Ruscoe WA, Wardle DA, Wilson DJ, Wright EF (2005) The hare, The tortoise and the crocodile: The ecology of angiosperm dominance, conifer persistence and fern filtering. Journal of Ecology, 93, 918-935.

Crowe T (1996) Different effects of microhabitat fragmentation on patterns of dispersal of an intertidal gastropod in two habitats. Journal of Experimental Marine Biology \& Ecology, 206, 83-107.

Cummings J, Martin M, Rogers A (2006) Quantifying the abundance of four large epiphytic fern species in remnant complex notophyll vine forest on the Atherton Tableland, North Queensland, Australia. Cunninghamia, 9, 521-527.

de Oliveira Xavier R, Dodonov P, da Silva Matos DM (2019) Growth and mortality patterns of the Neotropical bracken (Pteridium arachnoideum) and their response to shading in a savanna-riparian forest transition. Flora, 252, 36-43.

Dong M (2011) Clonal Plant Ecology. Science Press, Beijing. (in Chinese) [董鸣 (2011) 克隆植物生态学. 科学出版社, 北京.]

Dong M, Yu FH (2007) Terminology and concept of clonal plant ecology. Journal of Plant Ecology (Chinese Version), 31, 689-694. (in Chinese with English abstract) [董鸣, 于 飞海 (2007) 克隆植物生态学术语和概念. 植物生态学 报, 31, 689-694.]

Du J, Wang N, Alpert P, Yu MJ, Yu FH, Dong M (2010) Clonal integration increases performance of ramets of the fern Diplopterygium glaucum in an evergreen forest in southeastern China. Flora, 205, 399-403.

Dubuisson JY, Schneider H, Hennequin S (2009) Epiphytism in ferns: Diversity and history. Comptes Rendus Biologies, $332,120-128$.

Ellwood MD, Foster WA (2004) Doubling the estimate of inve- 
rtebrate biomass in a rainforest canopy. Nature, 429, 549-551.

Endler JA (1993) The color of light in forests and its implications. Ecological Monographs, 63, 1-27.

Farrar DR, Dassler CL, Watkins JE, Skelton C (2008) Gametophyte ecology. In: The Biology and Evolution of Ferns and Lycophytes (eds Ranker TA, Haufl CH), pp. 224-258. Cambridge University Press, Cambridge.

Flinn KM, Loiacono MM, Groff HE (2014) Low reproductive success of hay-scented fern (Dennstaedtia punctilobula) regardless of inbreeding level or time since disturbance. Botany, 92, 911-915.

Fujinuma J, Kusumoto B, Shiono T, Kubota Y (2019) Speciesspecific clonality in East Asian island flora: Phylogenetic and environmental constraints. Ecological Research, 34, 577-586.

George LO, Bazzaz FA (1999) The fern understory as an ecological filter: Growth and survival of canopy-tree seedlings. Ecology, 80, 846-856.

Goebel K (1905) Organography of Plants: Especially of the Archegoniatae and Spermaphyta. Part II. Special Organography (Facsimile of the 1905 Edition). Hafner, New York and London.

Guo W, Song YB, Yu FH (2011) Heterogeneous light supply affects growth and biomass allocation of the understory fern Diplopterygium glaucum at high patch contrast. PLoS ONE, 6, e27998.

Hallé F (1999) Ecology of reiteration in tropical trees. In: The Evolution of Plant Architecture (eds Kurmann MH, Hemsley AR), pp. 93-107. Royal Botanic Gardens, Kew.

Hartnett D, Bazzaz F (1983) Physiological integration among intraclonal ramets in Solidago canadensis. Ecology, 64, 779-788.

He Q, Bertness MD, Altieri AH (2013) Global shifts towards positive species interactions with increasing environmental stress. Ecology Letters, 16, 695-706.

He WM, Alpert P, Yu FH, Zhang LL, Dong M (2011) Reciprocal and coincident patchiness of multiple resources differentially affect benefits of clonal integration in two perennial plants. Journal of Ecology, 99, 1202-1210.

Hietz P (1997) Population dynamics of epiphytes in a Mexican humid montane forest. Journal of Ecology, 85, 767-775.

Hsu R, Wolf JHD (2009) Diversity and phytogeography of vascular epiphytes in a tropical-subtropical transition island, Taiwan. Flora, 204, 612-627.

Jackson JBC, Cook RE, Ashmun JW (1985) Population Biology and Evolution of Clonal Organisms. Yale University Press, New Haven.

Kawai H, Kanegae T, Christensen S, Kiyosue T, Sato Y, Imaizumi T, Kadota A, Wada M (2003) Responses of ferns to red light are mediated by an unconventional photoreceptor. Nature, 421, 287-290.

Klimeš L, Klimešová J, Hendriks R, van Groenendael J (1997)
Clonal plant architecture: A comparative analysis of form and function. In: The Ecology and Evolution of Clonal Plants (eds Kroon HD, Groenendael JV), pp. 1-29. Backhuys Publishers, Leiden.

Kuehnert CC (1967) Developmental potentialities of leaf primordia of Osmunda cinnamomea: The influence of determined leaf primordia on undetermined leaf primordia. Canadian Journal of Botany, 45, 2109-2113.

Li L, Yan YH (2014) Asexual reproduction of ferns. Garden, (3), 32-35. (in Chinese) [李莉, 严岳鸿 (2014) 硕类植物 的无性繁殖. 园林, (3), 32-35.]

Lowman M, Devy S, Ganesh T (2013) Treetops at Risk: Challenges of Global Canopy Ecology and Conservation. Springer Science \& Business Media, New York.

Lowman MD, Schowalter TD (2012) Plant science in forest canopies-The first 30 years of advances and challenges (1980-2010). New Phytologist, 194, 12-27.

Lu HZ (2017) Clonality and Ecological Adaptation Strategy of Epiphytic Ferns in Tropical and Subtropical Forests in Yunnan. PhD dissertation, Xishuangbanna Tropical and Botanical Garden, Chinese Academy of Science, Menglun, Yunnan. (in Chinese with English abstract) [卢华正 (2017) 云南热带和亚热带森林附生蕨类植物的克隆性及其生态 适应策略. 博士学位论文, 中国科学院西双版纳热带植 物园, 云南预腊.]

Lu HZ, Brooker R, Song L, Liu WY, Sack L, Zhang JL, Yu FH (2020) When facilitation meets clonal integration in forest canopies. New Phytologist, 225, 135-142.

Lu HZ, Liu WY, Yu FH, Song L, Xu XL, Wu CS, Zheng YL, Li YP, Gong HD, Chen K, Li S, Chen X, Qi JH, Lu SG (2015) Higher clonal integration in the facultative epiphytic fern Selliguea griffithiana growing in the forest canopy compared with the forest understory. Annals of Botany, 116, 113-122.

Lu HZ, Song L, Liu WY, Xu XL, Hu YH, Shi XM, Li S, Ma WZ, Chang YF, Fan ZX, Lu SG, Wu Y, Yu FH (2016) Survival and growth of epiphytic ferns depend on resource sharing. Frontiers in Plant Science, 7, 416.

Lu SG (2007) Pteridology. Higher Education Press, Beijing. (in Chinese) [陆树刚 (2007) 䒴类植物学. 高等教育出版社, 北京.]

Ma WZ (2009) The Composition and Biomass of Epiphytic Materials and Their Relationships with Ecological Factors in Xujiaba Region from Ailao Mountain, Yunnan. PhD dissertation, Xishuangbanna Tropical and Botanical Garden, Chinese Academy of Science, Menglun, Yunnan. (in Chinese with English abstract) [马文章 (2009) 云南哀牢山徐家坝地区 附生(植)物的组成、生物量及其与生态因子的关系. 博士 学位论文, 中国科学院研究生院西双版纳热带植物园, 云南预腊.]

Matsunaga KKS, Tomescu AMF (2017) An organismal concept for Sengelia radicans gen. et sp. nov. - Morphology and natural history of an Early Devonian lycophyte. Annals 
of Botany, 119, 1097-1113.

Medeiros JCC, Silva JCF, Resende TDC, Teodoro GS, Pereira FJ, Coelho FD (2018) Ramet versus sporocarp production in the aquatic fern Salvinia auriculata (Salviniaceae): The role of shading. Australian Journal of Botany, 66, 583-588.

Mehltreter K, Walker LR, Sharpe JM (2010) Fern Ecology. Cambridge University Press, Cambridge.

Mendieta-Leiva G, Zotz G (2015) A conceptual framework for the analysis of vascular epiphyte assemblages. Perspectives in Plant Ecology, Evolution and Systematics, 17, 510-521.

Nadkarni NM (1984) Epiphyte biomass and nutrient capital of a neotropical Elfin forest. Biotropica, 16, 249-256.

Nadkarni NM, Parker GG, Ford ED, Cushing JB, Stallman C (1996) The international canopy network: A pathway for interdisciplinary exchange of scientific information on forest canopies. Northwest Science, 70, 104-108.

Outridge P, Hutchinson T (1991) Induction of cadmium tolerance by acclimation transferred between ramets of the clonal fern Salvinia minima Baker. New phytologist, 117, 597-605.

Ozanne C, Anhuf D, Boulter S, Keller M, Kitching RL, Körner C, Meinzer FC, Mitchell A, Nakashizuka T, Dias PS (2003) Biodiversity meets the atmosphere: A global view of forest canopies. Science, 301,183-186.

Pickett FL (1931) Notes on xerophytic ferns. American Fern Journal, 21, 49-57.

Priestley JH, Swingle CF (1929) Vegetative propagation from the standpoint of plant anatomy. United States Department of Agriculture Technical Bulletin, 151, 1-98.

Richards JH, Beck JZ, Hirsch AM (1983) Structural investigations of asexual reproduction in Nephrolepis exaltata and Platycerium bifurcatum. American Journal of Botany, 70, 993-1001.

Robinson MR, Beckerman AP (2013) Quantifying multivariate plasticity: Genetic variation in resource acquisition drives plasticity in resource allocation to components of life history. Ecology Letters, 16, 281-290.

Robinson SC, Miller NG (2013) Bryophyte diversity on Adirondack alpine summits is maintained by dissemination and establishment of vegetative fragments and spores. Bryologist, 116, 382-391.

Schneider H, Schuettpelz E, Pryer KM, Cranfill R, Magallon S, Lupia R (2004) Ferns diversified in the shadow of angiosperms. Nature, 428, 553-557.

Schuettpelz E, Pryer KM (2009) Evidence for a Cenozoic radiation of ferns in an angiosperm-dominated canopy. Proceedings of the National Academy of Sciences, USA, 106, 11200-11205.

Slade AJ, Hutchings MJ (1987) The effects of nutrient availability on foraging in the clonal herb Glechoma hederacea. Journal of Ecology, 75, 95-112.

Smith AR, Pryer KM, Schuettpelz E, Korall P, Schneider H, Paul G, Wolf PG (2006) A classification for extant ferns. Taxon, 55, 705-731.
Song J, Li RH, Zhu SD, Ye Q (2013) Leaf functional traits of ferns from different habitats in monsoon evergreen broadleaved forest in Dinghushan Mountain. Journal of Tropical and Subtropical Botany, 21, 489-495. (in Chinese with English abstract) [宋娟, 李荣华, 朱师丹, 叶清 (2013) 鼎 湖山季风常绿阔叶林不同生境葓类植物的叶片功能性状 研究. 热带亚热带植物学报, 21, 489-495.]

Song YB, Yu FH, Keser LH, Dawson W, Fischer M, Dong M, van Kleunen M (2013) United we stand, divided we fall: A meta-analysis of experiments on clonal integration and its relationship to invasiveness. Oecologia, 171, 317-327.

Tang DD, Wu Y, Liu WY, Li DF, Yang GP, Chen Q, Zhang TT (2018) Diversity and floristic characteristics of vascular epiphytes in montane forests in the Ailao Mountains, Yunnan. Plant Science Journal, 36, 658-666. (in Chinese with English abstract) [汤丹丹, 吴毅, 刘文耀, 李德飞, 杨国 平, 陈泉, 张婷婷 (2018) 云南哀牢山地区森林附生维管 植物多样性及区系特征. 植物科学学报, 36, 658-666. ]

Tomescu AMF, Rothwell GW, Trivett ML (2008) Reiterative growth in the complex adaptive architecture of the Paleozoic (Pennsylvanian) filicalean fern Kaplanopteris clavate. Plant Systematics and Evolution, 270, 209-216.

Trewavas A (2005) Green plants as intelligent organisms. Trends in Plant Science, 10, 413-419.

Tsutsumi C, Kato M (2006) Evolution of epiphytes in Davalliaceae and related ferns. Botanical Journal of the Linnean Society, 151, 495-510.

Watkins JE, Holbrook NM, Zwieniecki MA (2010) Hydraulic properties of fern sporophytes: Consequences for ecological and evolutionary diversification. American Journal of Botany, 97, 2007-2019.

Watkins JE, Mack MC, Sinclair TR, Mulkey SS (2007) Ecological and evolutionary consequences of desiccation tolerance in tropical fern gametophytes. New Phytologist, 176, 708-717.

Wu Y, Song L, Liu Q, Zhao MX, Lu HZ, Tan YH, Liu WY (2016) Diversity and floristic characteristics of vascular epiphytes in the tropical forest of Xishuangbanna. Biodiversity Science, 24, 271-279. (in Chinese with English abstract) [吴 毅, 宋亮, 刘强, 赵明旭, 卢华正, 谭运洪, 刘文耀 (2016) 西双版纳热带森林附生维管植物的物种多样性与 区系特征. 生物多样性, 24, 271-279.]

Xu CD, Li XL, Feng JM (2011) Relationships between epiphyte ferns species diversity and their phorophytes in Mt. Ailao National Nature Reserve. Chinese Journal of Ecology, 30, 1858-1862. (in Chinese with English abstract) [徐成东, 李雪玲, 冯建孟 (2011) 云南哀牢山国家级自然保护区 附生硕类植物的多样性与附载植物的关系. 生态学杂志, 30, 1858-1862.]

Xu CD, Lu SG (2006) Pteridophytes floristic phytogeography in Mt. Ailaoshan National Nature Reserve of Yunnan, China. Acta Botanica Boreali-Occidentalia Sinica, 26, 2351-2359. (in Chinese with English abstract) [徐成东, 陆 
树刚 (2006) 云南哀牢山国家级自然保护区烣类植物区 系地理研究. 西北植物学报, 26, 2351-2359.]

Xu HQ, Liu WY (2005) Species diversity and distribution of epiphytes in the montane moist evergreen broad-leaved forest in Ailao Mountain, Yunnan. Biodiversity Science, 13, 137-147. (in Chinese with English abstract) [徐海清, 刘文 耀 (2005) 云南哀牢山山地湿性常绿阔叶林附生植物的 多样性和分布. 生物多样性, 13, 137-147.]

Xu L, Yu FH, van Drunen E, Schieving F, Dong M, Anten NPR (2012) Trampling, defoliation and physiological integration affect growth, morphological and mechanical properties of a root-suckering clonal tree. Annals of Botany, 109, 1001-1008.

Yu FH, Dong M, Krüsi B (2004) Clonal integration helps Psammochloa villosa survive sand burial in an inland dune. New Phytologist, 162, 697-704.

Zhang LM, Alpert P, Si C, Yu FH (2019a) Interactive effects of fragment size, nutrients, and interspecific competition on growth of the floating, clonal plant Salvinia natans. Aquatic Botany, 153, 81-87.

Zhang LM, Lu HZ, Alpert P, Song L, Liu WY, Yu FH (2019b) Higher benefits of clonal integration in rhizome-derived than in frond-derived ramets of the tropical fern Bolbitis heteroclita. Flora, 257, 151415.

Zhang Q, Chen JW, Li BG, Cao KF (2009a) The effect of drought on photosynthesis in two epiphytic and two terrestrial tropical fern species. Photosynthetica, 47, 128-132.

Zhang Q, Chen JW, Li BG, Cao KF (2009b) Epiphytes and hemiepiphytes have slower photosynthetic response to lightflecks than terrestrial plants: Evidence from ferns and figs. Journal of Tropical Ecology, 25, 465-472.

Zhang WP, Pan S, Jia X, Chu CJ, Xiao S, Lin Y, Bai YY,
Wang GX (2013) Effects of positive plant interactions on population dynamics and community structures: A review based on individual-based simulation models. Chinese Journal of Plant Ecology, 37, 571-582. (in Chinese with English abstract) [张炜平, 潘莎, 贾昕, 储诚进, 肖酒, 林玥, 白 燕远, 王根轩 (2013) 植物间正相互作用对种群动态和 群落结构的影响: 基于个体模型的研究进展. 植物生态 学报, 37, 571-582.]

Zhang XC (2012) Lycophytes and Ferns of China. Peking University Press, Beijing. (in Chinese) [张宪春 (2012) 中 国石松类和偋类植物. 北京大学出版社, 北京.]

Zhang YF, Zhang DY (2006) Asexual and sexual reproductive strategies in clonal plants. Journal of Plant Ecology (Chinese Version), 30, 174-183. (in Chinese with English abstract) [张玉芬, 张大勇 (2006) 克隆植物的无性与有性繁殖对 策. 植物生态学报, 30, 174-183.]

Zhu SD, Li RH, Song J, He PC, Liu H, Berninger F, Ye Q (2016) Different leaf cost-benefit strategies of ferns distributed in contrasting light habitats of sub-tropical forests. Annals of Botany, 117, 497-506.

Zotz G (2013) The systematic distribution of vascular epiphytes: A critical update. Botanical Journal of the Linnean Society, 171, 453-481.

Zotz G, Hietz P (2001) The physiological ecology of vascular epiphytes: Current knowledge, open questions. Journal of Experimental Botany, 52, 2067-2078.

Zotz G, Winter K (1994) Annual carbon balance and nitrogen-use efficiency in tropical $\mathrm{C}_{3}$ and CAM epiphytes. New Phytologist, 126, 481-492.

(责任编委: 严岳鸿 责任编辑: 黄祥忠)

\section{附录 Supplementary Material}

附录1 哀牢山亚热带山地森林的附生丵类植物名录及其根状茎特征汇编

Appendix 1 Fern species biodiversity and traits of their rhizome in subtropical forests in Ailao Mountains http://www.biodiversity-science.net/fileup/PDF/2019120-1.pdf

附录2 西双版纳热带森林的附生莿类植物名录及其根状茎特征汇编

Appendix 2 Fern species biodiversity and traits of their rhizome in tropical forests in Xishuangbanna http://www.biodiversity-science.net/fileup/PDF/2019120-2.pdf 
孙晶琦, 陈泉, 李航宇, 常艳芬, 巩合德, 宋亮, 卢华正. 附生蕨类植物的克隆性研究进展. 生物多样性, 2019, 27 (11): 1184-1195. http://www.biodiversity-science.net/CN/10.17520/biods.2019120

附录1 哀牢山亚热带山地森林的附生硕类植物名录及其根状茎特征汇编

Appendix 1 Fern species biodiversity and traits of their rhizome in subtropical forests in Ailao Mountains

\begin{tabular}{|c|c|c|}
\hline 种 Species & 根状茎 Rhizome & 附生/石生 Epiphytic/Ishio \\
\hline \multicolumn{3}{|l|}{ 凤尾烣科 Pteridaceae } \\
\hline \multicolumn{3}{|l|}{ 铁线蕨属 Adiantum } \\
\hline 铁线䓢 Adiantum capillus-veneris & 长而横走 & 石生 \\
\hline 鞭叶铁线硕 Adiantum caudatum & 短而直立 & 石生 \\
\hline 月牙铁线菜 Adiantum edentulum & 短而直立 & 石生 \\
\hline 普通铁线硕 Adiantum edgeworthii & 短而直立 & 石生 \\
\hline 假鞭叶铁线蕨 Adiantum malesianum & 短而直立 & 石生 \\
\hline \multicolumn{3}{|l|}{ 粉背硕属 Aleuritopteris } \\
\hline 白边粉背硕 Aleuritopteris albomarginata & 短而直立 & 石生 \\
\hline 粉背硕 Aleuritopteris anceps & 短而直立 & 石生 \\
\hline \multicolumn{3}{|l|}{ 车前硕属 Antrophyum } \\
\hline 车前硕 Antrophyum henryi & 短而直立 & 附生/石生 \\
\hline 长柄车前硕 Antrophyum obovatum & 短而直立 & 附生/石生 \\
\hline \multicolumn{3}{|l|}{ 戟叶黑心蕨属 Calciphilopteris } \\
\hline 戟叶黑心硕 Calciphilopteris ludens & 长而横走 & 石生 \\
\hline \multicolumn{3}{|l|}{ 碎米蕨属 Cheilanthes } \\
\hline 薄叶碎米濒 Cheilanthes tenuifolia & 短而直立 & 石生 \\
\hline \multicolumn{3}{|l|}{ 书带蕨属 Haplopteris } \\
\hline 带状书带萨 Haplopteris doniana & 短而横走 & 附生/石生 \\
\hline 书带硕 Haplopteris flexuosa & 短而横走 & 附生/石生 \\
\hline 曲鳞书带硕 Haplopteris plurisulcata & 短而横走 & 附生/石生 \\
\hline \multicolumn{3}{|l|}{ 金毛裸硕属 Paragymnopteris } \\
\hline 金毛裸䲞 Paragymnopteris vestita & 短而横走 & 石生 \\
\hline \multicolumn{3}{|l|}{ 旱蓱属 Pellaea } \\
\hline 旱䓲 Pellaea nitidula & 短而直立 & 石生 \\
\hline \multicolumn{3}{|l|}{ 凤尾䕬属 Pteris } \\
\hline 岩凤尾硕 Pteris deltodon & 短而直立 & 石生 \\
\hline 狭叶凤尾蕨 Pteris henryi & 短而直立 & 石生 \\
\hline 井栏边草 Pteris multifida & 短而直立 & 石生 \\
\hline 蜈蚣蕨 Pteris vittata & 短而直立 & 石生 \\
\hline \multicolumn{3}{|l|}{ 水龙骨科 Polypodiaceae } \\
\hline \multicolumn{3}{|l|}{ 节肢硕属 Arthromeris } \\
\hline 节肢硕 Arthromeris lehmannii & 长而横走 & 附生/石生 \\
\hline 康定节肢菜 Arthromeris tatsienensis & 横走 & 石生 \\
\hline 单行节肢蓱 Arthromeris wallichiana & 横走 & 附生/石生 \\
\hline 灰背节肢蕨 Arthromeris wardii & 横走 & 附生 \\
\hline \multicolumn{3}{|l|}{ 葪蕨属 Drynaria } \\
\hline 团叶葪蕨 Drynaria bonii & 横走 & 附生/石生 \\
\hline 川滇楋锁 Drynaria delavayi & 横走 & 石生 \\
\hline 椡蕨 Drynaria fortunei & 横走 & 附生/石生 \\
\hline 石莲姜葪濒 Drynaria propinqua & 横走 & 附生 \\
\hline \multicolumn{3}{|l|}{ 棱脉蕨属 Goniophlebium } \\
\hline 柔毛水龙骨 Goniophlebium amoena var. pilosa & 长而横走 & 附生 \\
\hline 友水龙骨 Goniophlebium amoenum & 长而横走 & 附生/石生 \\
\hline 尖齿拟水龙骨 Goniophlebium argutum & 长而横走 & 附生 \\
\hline 濑水龙骨 Goniophlebium lachnopus & 长而横走 & 附生/石生 \\
\hline 篦齿蕨 Goniophlebium manmeiense & 长而横走 & 附生/石生 \\
\hline 蒙自拟水龙骨 Goniophlebium mengtzeense & 长而横走 & 附生/石生 \\
\hline 栗柄水龙骨 Goniophlebium microrhizoma & 长而横走 & 附生/石生 \\
\hline 假毛柄水龙骨 Goniophlebium pseudolachnopus* & 长而横走 & 附生 \\
\hline 拟水龙骨 Goniophlebium sp. & 长而横走 & 附生 \\
\hline 假友水龙骨 Goniophlebium subamoena & 长而横走 & 附生 \\
\hline 光茎水龙骨 Goniophlebium wattii & 长而横走 & 附生 \\
\hline \multicolumn{3}{|l|}{ 雨蕨属 Gymnogrammitis } \\
\hline 雨蕨 Gymnogrammitis dareiformis & 长而横走 & 附生 \\
\hline \multicolumn{3}{|l|}{ 伏石蕨属 Lemmaphyllum } \\
\hline 肉质伏石瘩 Lemmaphyllum carnosum & 长而横走 & 附生/石生 \\
\hline 骨牌硕 Lemmaphyllum rostratum & 长而横走 & 附生/石生 \\
\hline 鳞果星蕨属 Lepidomicrosorium & & \\
\hline 表面星蕨 Lepidomicrosorium superficiale & 长而横走 & 附生/石生 \\
\hline 瓦韦属 Lepisorus & & \\
\hline 二色瓦韦 Lepisorus bicolor & 长而横走 & 石生 \\
\hline
\end{tabular}


孙晶琦, 陈泉, 李航宇, 常艳芬, 巩合德, 宋亮, 卢华正. 附生硕类植物的克隆性研究进展. 生物多样性, 2019, 27 (11): 1184-1195. http://www.biodiversity-science.net/CN/10.17520/biods.2019120

\begin{tabular}{|c|c|c|}
\hline 种 Species & 根状茎 Rhizome & 附生/石生 Epiphytic/Ishio \\
\hline 汇生瓦韦 Lepisorus confluens & 长而横走 & 附生/石生 \\
\hline 扭瓦韦 Lepisorus contortus & 长而横走 & 附生/石生 \\
\hline 瑶山瓦韦 Lepisorus kuchenensis & 长而横走 & 附生/石生 \\
\hline 带叶瓦韦 Lepisorus loriformis & 长而横走 & 附生/石生 \\
\hline 大瓦韦 Lepisorus macrosphaerus & 长而横走 & 附生 \\
\hline 小叶瓦韦 Lepisorus macrosphaerus f. minimus & 长而横走 & 附生/石生 \\
\hline 粤瓦韦 Lepisorus obscure-venulosus & 长而横走 & 附生/石生 \\
\hline 稀鳞瓦韦 Lepisorus oligolepidus & 长而横走 & 附生/石生 \\
\hline 棕鳞瓦韦 Lepisorus scolopendrium & 长而横走 & 附生/石生 \\
\hline 中华瓦韦 Lepisorus sinensis & 长而横走 & 附生/石生 \\
\hline 滇瓦韦 Lepisorus sublinearis & 长而横走 & 附生/石生 \\
\hline 瓦韦 Lepisorus thunbergianus & 长而横走 & 附生 \\
\hline \multicolumn{3}{|l|}{ 薄唇蕨属 Leptochilus } \\
\hline 似薄唇蕨 Leptochilus decurrens & 长而横走 & 附生/石生 \\
\hline 线鰀 Leptochilus ellipticus & 长而横走 & 石生 \\
\hline \multicolumn{3}{|l|}{ 剑蕨属 Loxogramme } \\
\hline 黑鳞剑烣 Loxogramme assimilis & 长而横走 & 附生/石生 \\
\hline 中华剑蕨 Loxogramme chinensis & 长而横走 & 附生/石生 \\
\hline 褐柄剑萨 Loxogramme duclouxii & 长而横走 & 附生/石生 \\
\hline 柳叶剑蕨 Loxogramme salicifolia & 长而横走 & 附生/石生 \\
\hline \multicolumn{3}{|l|}{ 锯蕨属 Miorpopypodium } \\
\hline 锡金锯蕨 Micropolypodium sikkimense & 直立 & 附生/石生 \\
\hline \multicolumn{3}{|l|}{ 星硕属 Microsorum } \\
\hline 羽裂星蕨 Microsorum insigne & 长而横走 & 石生 \\
\hline 膜叶星蕨 Microsorum membranaceum & 长而横走 & 附生/石生 \\
\hline \multicolumn{3}{|l|}{ 盾葓属 Neolepisorus } \\
\hline 江南星蕨 Neolepisorus fortunei & 长而横走 & 附生/石生 \\
\hline 盾烣 Neolepisorus ovatus & 长而横走 & 附生/石生 \\
\hline \multicolumn{3}{|l|}{ 假濾葓属 Phymatopteris } \\
\hline 白茎假瘤菜 Phymatopteris chrysotricha & 长而横走 & 附生 \\
\hline 耿马假瘤蕨 Phymatopteris connexa & 长而横走 & 附生 \\
\hline 紫柄假瘤媭 Phymatopteris crenatopinnata & 长而横走 & 附生 \\
\hline 弯弓假瘤硕 Phymatopteris malacodon & 长而横走 & 附生/石生 \\
\hline 大果假瘤濒 Phymatopteris griffithiana & 长而横走 & 附生/石生 \\
\hline 尖裂假瘤菜 Phymatopteris oxyloba & 长而横走 & 附生/石生 \\
\hline 喙叶假瘤硕 Phymatopteris rhynchophylla & 长而横走 & 附生/石生 \\
\hline 尾尖假瘤颐 Phymatopteris stewartii & 长而横走 & 附生/石生 \\
\hline 三出假瘤䕬 Phymatopteris trisecta & 长而横走 & 附生 \\
\hline 黑鳞假瘤蕨 Phymatopteris ebenipes & 长而横走 & 附生/石生 \\
\hline \multicolumn{3}{|l|}{ 瘤藏属 Phymatosorus } \\
\hline 光亮瘤蕨 Phymatosorus cuspidatus & 长而横走 & 石生 \\
\hline \multicolumn{3}{|l|}{ 石韦属 Pyrrosia } \\
\hline 光石韦 Pyrrosia calvata & 短而横走 & 附生/石生 \\
\hline 下延叶石韦 Pyrrosia costata & 短而横走 & 附生/石生 \\
\hline 华北石韦 Pyrrosia davidii & 短而横走 & 附生/石生 \\
\hline 轳毛石韦 Pyrrosia drakeana & 短而横走 & 附生/石生 \\
\hline 纸质石韦 Pyrrosia heteractis & 长而横走 & 附生/石生 \\
\hline 石韦 Pyrrosia lingua & 长而横走 & 附生/石生 \\
\hline 蔓氏石韦 Pyrrosia mannii & 短而横走 & 附生/石生 \\
\hline 裸叶石韦 Pyrrosia nuda & 长而横走 & 附生/石生 \\
\hline 裸柄石韦 Pyrrosia nudaicaulis* & 长而横走 & 附生/石生 \\
\hline 钱币石韦 Pyrrosia nummulariifolia & 长而横走 & 石生 \\
\hline 柔软石韦 Pyrrosia porosa & 短而横走 & 附生/石生 \\
\hline 拟毡毛石韦 Pyrrosia pseudodrakeana* & 短而横走 & 附生/石生 \\
\hline 庐山石韦 Pyrrosia sheareri & 横走 & 附生/石生 \\
\hline 线毛石韦 Pyrrosia subfurfuracea & 短而横走 & 附生/石生 \\
\hline \multicolumn{3}{|l|}{ 革舌硕属 Tomophyllum } \\
\hline 虎尾蒿硕 Tomophyllum donianum & 短而直立 & 附生/石生 \\
\hline \multicolumn{3}{|l|}{ 毛鳞釉属 Tricholepidium } \\
\hline 毛鳞硕 Tricholepidium normale & 直立 & 附生 \\
\hline \multicolumn{3}{|l|}{ 铁角烣科 Aspleniaceae } \\
\hline \multicolumn{3}{|l|}{ 铁角蕨属 Asplenium } \\
\hline 水鳖嵚 Asplenium delavayi & 短而直立 & 石生 \\
\hline 剑叶铁角䕬 Asplenium ensiforme & 短而直立 & 石生 \\
\hline 线叶铁角䕬 Asplenium ensiforme f. stenophyllum & 短而直立 & 石生 \\
\hline
\end{tabular}


孙晶琦, 陈泉, 李航宇, 常艳芬, 巩合德, 宋亮, 卢华正. 附生硕类植物的克隆性研究进展. 生物多样性, 2019, 27 (11): 1184-1195. http://www.biodiversity-science.net/CN/10.17520/biods.2019120

\begin{tabular}{|c|c|c|}
\hline 种 Species & 根状茎 Rhizome & 附生/石生 Epiphytic / Ishio \\
\hline 厚叶铁角䓲 Asplenium griffithianum & 短而直立 & 石生 \\
\hline 撕裂铁角蕨 Asplenium gueinzianum & 短而直立 & 石生 \\
\hline 胎生铁角硕 Asplenium indicum & 短而直立 & 附生/石生 \\
\hline 江南铁角菜 Asplenium loxogrammioides & 短而直立 & 石生 \\
\hline 倒挂铁角蓱 Asplenium normale & 短而直立 & 石生 \\
\hline 疏脉苍山蕨 Asplenium paucivenosum & 短而直立 & 石生 \\
\hline 西南铁角媭 Asplenium praemorsum & 短而直立 & 石生 \\
\hline 长叶铁角䕬 Asplenium prolongatum & 短而直立 & 附生/石生 \\
\hline 细裂铁角蕨 Asplenium tenuifolium & 短而直立 & 附生/石生 \\
\hline 变异铁角蕨 Asplenium varians & 短而直立 & 附生/石生 \\
\hline 棕鳞铁角蕨 Asplenium yoshinagae & 短而直立 & 附生/石生 \\
\hline \multicolumn{3}{|l|}{ 膜叶铁角葓属 Hymenasplenium } \\
\hline 无配膜叶铁角硕 Hymenasplenium apogamum & 长而横走 & 附生/石生 \\
\hline 切边膜叶铁角硕 Hymenasplenium excisum & 短而直立 & 石生 \\
\hline 荫湿膜叶铁角蕨 Hymenasplenium obliquissimum & 长而横走 & 石生 \\
\hline 微凹膜叶铁角蕨 Hymenasplenium retusulum & 长而横走 & 附生/石生 \\
\hline \multicolumn{3}{|l|}{ 蹄盖蕨科 Athyriaceae } \\
\hline \multicolumn{3}{|l|}{ 蹄盖蕨属 Athyrium } \\
\hline 红苍蹄盖蕨 Athyrium nakanoi & 短而直立 & 石生 \\
\hline \multicolumn{3}{|l|}{ 鳞毛蕨科 Dryopteridaceae } \\
\hline \multicolumn{3}{|l|}{ 实瞢属 Bolbitis } \\
\hline 多羽实谥 Bolbitis angustipinna & 短而横走 & 石生 \\
\hline 长叶实葻 Bolbitis heteroclita & 短而横走 & 附生/石生 \\
\hline 中华刺蕨 Bolbitis sinensis & 短而横走 & 附生/石生 \\
\hline 镰裂刺蕨 Bolbitis tonkinensis & 短而横走 & 石生 \\
\hline \multicolumn{3}{|l|}{ 贯众属 Cyrtomium } \\
\hline 等基贯众 Cyrtomium aequibasis & 短而直立 & 石生 \\
\hline \multicolumn{3}{|l|}{ 舌蒝属 Elaphoglossum } \\
\hline 舌蕨 Elaphoglossum conforme & 短而横走 & 附生/石生 \\
\hline 华南舌蓛 Elaphoglossum yoshinagae & 短而横走 & 附生/石生 \\
\hline \multicolumn{3}{|l|}{ 石盖蕨属 Lithostegia } \\
\hline 石盖蕨 Lithostegia foeniculacea & 长而横走 & 附生/石生 \\
\hline \multicolumn{3}{|l|}{ 耳硕属 Polystichum } \\
\hline 陈氏耳蒝 Polystichum chunii & 短而直立 & 石生 \\
\hline 黑鳞耳偋 Polystichum makinoi & 短而直立 & 石生 \\
\hline 乌鳞耳蕨 Polystichum piceopaleaceum & 短而直立 & 石生 \\
\hline \multicolumn{3}{|l|}{ 膜蕨科 Hymenophyllaceae } \\
\hline \multicolumn{3}{|l|}{ 假脉鄀属 Crepidomanes } \\
\hline 翅柄假脉蓀 Crepidomanes latealatum & 纤细横走 & 附生 \\
\hline \multicolumn{3}{|l|}{ 膜蕨属 Hymenophyllum } \\
\hline 蕗濒 Hymenophyllum badium & 长而横走 & 附生/石生 \\
\hline 华东膜硕 Hymenophyllum barbatum* & 长而横走 & 附生/石生 \\
\hline 毛蕗硕 Hymenophyllum exsertum & 横走 & 附生/石生 \\
\hline 线叶蕗蕨 Hymenophyllum longissimum & 长而横走 & 附生/石生 \\
\hline 长柄蕗偋 Hymenophyllum polyanthos & 长而横走 & 附生/石生 \\
\hline 未知膜蕨 Hymenophyllum sp. & 长而横走 & 附生/石生 \\
\hline \multicolumn{3}{|l|}{ 瓶嵚属 Vandenboschia } \\
\hline 瓶蕨 Vandenboschia auriculata & 长而横走 & 附生/石生 \\
\hline 南海瓶蕨 Vandenboschia striata & 长而横走 & 附生/石生 \\
\hline \multicolumn{3}{|l|}{ 金星㡀科 Thelypteridaceae } \\
\hline \multicolumn{3}{|l|}{ 毛蕨属 Cyclosorus } \\
\hline 普通假毛蕨 Cyclosorus subochthodes & 短而横走 & 石生 \\
\hline 假毛硕 Cyclosorus tylodes & 短而横走 & 石生 \\
\hline 骨碎补科 Davalliaceae & & \\
\hline 骨碎补属 Davallia & & \\
\hline 细裂小膜盖硕 Davallia faberiana & 长而横走 & 附生 \\
\hline 宿枝小膜盖藃 Davallia hookeri & 长而横走 & 附生/石生 \\
\hline 膜叶假钻毛偋 Davallia membranulosum & 长而横走 & 附生/石生 \\
\hline 鳞轴小膜盖㷇 Davallia perdurans & 长而横走 & 附生/石生 \\
\hline 半圆盖阴石蕨 Davallia platylepis & 长而横走 & 附生/石生 \\
\hline 长片小膜盖蕨 Davallia pseudocystopteris & 长而横走 & 附生/石生 \\
\hline 阴石硕 Davallia repens & 长而横走 & 附生/石生 \\
\hline 肿足烣科 Hypodematiaceae & & \\
\hline 大膜盖蕨属 Leucostegia & & \\
\hline 大膜盖硕 Leucostegia truncata & 长而横走 & 附生/石生 \\
\hline
\end{tabular}


孙晶琦, 陈泉, 李航宇, 常艳芬, 巩合德, 宋亮, 卢华正. 附生硕类植物的克隆性研究进展. 生物多样性, 2019, 27 (11): 1184-1195. http://www.biodiversity-science.net/CN/10.17520/biods.2019120

\begin{tabular}{|c|c|c|}
\hline 种 Species & 根状茎 Rhizome & 附生/石生 Epiphytic / Ishio \\
\hline \multicolumn{3}{|l|}{ 石松科 Lycopodiaceae } \\
\hline \multicolumn{3}{|l|}{ 石松属 Lycopodium } \\
\hline 石松 Lycopodium japonicum & 纤细横走 & 石生 \\
\hline \multicolumn{3}{|l|}{ 垂穗石松属 Palhinhaea } \\
\hline 垂穗石松 Palhinhaea cernua & 直立 & 石生 \\
\hline \multicolumn{3}{|l|}{ 碗粢科 Dennstaedtiaceae } \\
\hline \multicolumn{3}{|l|}{ 鳞盖蒴属 Microlepia } \\
\hline 粗毛鳞盖蕨 Microlepia strigosa & 长而横走 & 石生 \\
\hline \multicolumn{3}{|l|}{ 肾蕨科 Nephrolepidaceae } \\
\hline \multicolumn{3}{|l|}{ 肾蒝属 Nephrolepis } \\
\hline 肾硕 Nephrolepis cordifolia & 直立 & 附生 \\
\hline \multicolumn{3}{|l|}{ 条糇科 Oleandraceae } \\
\hline \multicolumn{3}{|l|}{ 条葓属 Oleandra } \\
\hline 华南条蕨 Oleandra cumingii & 长而横走 & 石生 \\
\hline 高山条蕨 Oleandra wallichii & 长而横走 & 附生 \\
\hline \multicolumn{3}{|l|}{ 鳞始濒科 Lindsaeaceae } \\
\hline \multicolumn{3}{|l|}{ 香鳞始蕨属 Osmolindsaea } \\
\hline 鳞始蕨 Osmolindsaea odorata & 长而横走 & 附生 \\
\hline \multicolumn{3}{|l|}{ 松叶蕨科 Psilotaceae } \\
\hline \multicolumn{3}{|l|}{ 松叶硕属 Psilotum } \\
\hline 松叶硕 Psilotum nudum & 横走 & 附生/石生 \\
\hline \multicolumn{3}{|l|}{ 卷柏科 Selaginellaceae } \\
\hline \multicolumn{3}{|l|}{ 卷柏属 Selaginella } \\
\hline 蔓出卷柏 Selaginella davidii & 直立 & 石生 \\
\hline 薄叶卷柏 Selaginella delicatula & 直立 & 石生 \\
\hline 异穗卷柏 Selaginella heterostachys & 横走 & 石生 \\
\hline 印度卷柏 Selaginella indica & 横走 & 石生 \\
\hline 充州卷柏 Selaginella involvens & 直立 & 附生/石生 \\
\hline 膜叶卷柏 Selaginella leptophylla & 直立 & 石生 \\
\hline 江南卷柏 Selaginella moellendorffii & 长而横走 & 石生 \\
\hline 卷柏 Selaginella tamariscina & 直立 & 石生 \\
\hline 细瘦卷柏 Selaginella vardei & 长而横走 & 石生 \\
\hline
\end{tabular}


孙晶琦, 陈泉, 李航宇, 常艳芬, 巩合德, 宋亮, 卢华正. 附生蕨类植物的克隆性研究进展. 生物多样性, 2019, 27 (11): 1184-1195. http://www.biodiversity-science.net/CN/10.17520/biods.2019120

附录2 西双版纳热带森林的附生蔴类植物名录及其根状茎特征汇编

Appendix 2 Fern species biodiversity and traits of their rhizome in tropical forests in Xishuangbanna

\begin{tabular}{|c|c|c|}
\hline 种 Species & 根状茎 Rhizome & 附生/石生 Epiphytic / Ishio \\
\hline \multicolumn{3}{|l|}{ 凤尾蕨科 Pteridaceae } \\
\hline \multicolumn{3}{|l|}{ 铁线蕨属 Adiantum } \\
\hline 团羽铁线蕨 Adiantum capillus-junonis & 直立 & 石生 \\
\hline 鞭叶铁线硕 Adiantum caudatum & 直立 & 石生 \\
\hline 荷叶铁线萨 Adiantum nelumboides ${ }^{*}$ & 直立 & 石生 \\
\hline \multicolumn{3}{|l|}{ 车前蕨属 Antrophyum } \\
\hline 美叶车前薑 Antrophyum callifolium & 横卧 & 附生/石生 \\
\hline 车前蕨 Antrophyum henryi & 横卧/直立 & 附生/石生 \\
\hline 长柄车前蒝 Antrophyum obovatum & 直立 & 附生/石生 \\
\hline 书带车前蒝 Antrophyum vittarioides & 横走 & 附生/石生 \\
\hline \multicolumn{3}{|l|}{ 书带鄀属 Haplopteris } \\
\hline 唇边书带薑 Haplopteris elongata & 横走 & 附生/石生 \\
\hline 书带䕋 Haplopteris flexuosa & 横走 & 附生/石生 \\
\hline \multicolumn{3}{|l|}{ 水龙骨科 Polypodiaceae } \\
\hline \multicolumn{3}{|l|}{ 连珠藏属 Aglaomorpha } \\
\hline 顶育濒 Aglaomorpha acuminate & 横走 & 石生 \\
\hline 崖姜 Aglaomorpha coronans & 横卧 & 附生/石生 \\
\hline \multicolumn{3}{|l|}{ 节肢蕨属 Arthromeris } \\
\hline 单行节肢硕 Arthromeris wallichiana & 横走 & 附生/石生 \\
\hline \multicolumn{3}{|l|}{ 葪蕨属 Drynaria } \\
\hline 团叶葪蕨 Drynaria bonii & 横走 & 附生/石生 \\
\hline 小槲蕨 Drynaria parishii & 匍匐 & 附生/石生 \\
\hline 石莲姜桷葓 Drynaria propinqua & 横走 & 附生/石生 \\
\hline 栋叶桷葓 Drynaria quercifolia & 横走 & 附生/石生 \\
\hline 硬叶桷菜 Drynaria rigidula & 攀绕 & 附生/石生 \\
\hline 葪葓 Drynaria roosii & 匍匐 & 附生/石生 \\
\hline \multicolumn{3}{|l|}{ 棱脉蕨属 Goniophlebium } \\
\hline 友水龙骨 Goniophlebium amoenum & 横走 & 附生/石生 \\
\hline 尖齿拟水龙骨 Goniophlebium argutum & 横走 & 附生/石生 \\
\hline 濑水龙骨 Goniophlebium lachnopus & 横走 & 附生/石生 \\
\hline 日本水龙骨 Goniophlebium niponica & 横走 & 附生/石生 \\
\hline 水龙骨一种 Goniophlebium sp. & 长而横走 & 附生 \\
\hline 穴果棱脉蒴 Goniophlebium subauriculatum & 横走 & 附生 \\
\hline \multicolumn{3}{|l|}{ 伏石蕨属 Lemmaphyllum } \\
\hline 肉质伏石葓 Lemmaphyllum carnosum & 横走 & 附生/石生 \\
\hline 披针骨牌硕 Lemmaphyllum diversum & 横走 & 石生 \\
\hline 抱石莲 Lemmaphyllum drymoglossoides & 横走 & 附生/石生 \\
\hline 伏石蒴 Lemmaphyllum microphyllum & 横走 & 附生/石生 \\
\hline 倒卵伏石菜 Lemmaphyllum microphyllum C. Presl var. obovatum ${ }^{*}$ & 横走 & 附生 \\
\hline 骨牌硕 Lemmaphyllum rostratum & 横走 & 附生/石生 \\
\hline \multicolumn{3}{|l|}{ 鳞果星菜属 Lepidomicrosorium } \\
\hline 表面星硕 Lepidomicrosorium superficiale & 攀援 & 附生/石生 \\
\hline \multicolumn{3}{|l|}{ 瓦韦属 Lepisorus } \\
\hline 狭叶瓦韦 Lepisorus angustus & 横走 & 附生/石生 \\
\hline 二色瓦韦 Lepisorus bicolor & 横走 & 附生/石生 \\
\hline 隐柄尖嘴蕨 Lepisorus henryi & 横卧 & 附生/石生 \\
\hline 大瓦韦 Lepisorus macrosphaerus & 横走 & 附生/石生 \\
\hline 粤瓦韦 Lepisorus obscurevenulosus & 横走 & 附生/石生 \\
\hline 稀鳞瓦韦 Lepisorus oligolepidus & 横走 & 附生/石生 \\
\hline 棕鳞瓦韦 Lepisorus scolopendrium & 横走 & 附生/石生 \\
\hline 中华瓦韦 Lepisorus sinensis & 横走 & 附生/石生 \\
\hline 瓦韦一种 Lepisorus sp. & 长而横走 & 附生 \\
\hline 滇瓦韦 Lepisorus sublinearis & 横走 & 附生/石生 \\
\hline 瓦韦 Lepisorus thunbergianus & 横走 & 附生/石生 \\
\hline 阔叶瓦韦 Lepisorus tosaensis & 横卧 & 附生/石生 \\
\hline \multicolumn{3}{|l|}{ 薄唇蕨属 Leptochilus } \\
\hline 薄唇蕨 Leptochilus axillaris & 攀援 & 附生 \\
\hline 似薄唇葓 Leptochilus decurrens & 横走 & 附生/石生 \\
\hline 掌叶线蕨 Leptochilus digitatus & 横走 & 石生 \\
\hline 线蕨 Leptochilus ellipticus & 长而横走 & 石生 \\
\hline 宽羽线蓱 Leptochilus ellipticus var. pothifolius & 横走 & 石生 \\
\hline 断线葓 Leptochilus hemionitideus & 横走 & 石生 \\
\hline 褐叶线萨 Leptochilus wrightii & 横走 & 石生 \\
\hline 剑蓱属 Loxogramme & & \\
\hline
\end{tabular}


孙晶琦, 陈泉, 李航宇, 常艳芬, 巩合德, 宋亮, 卢华正. 附生蒴类植物的克隆性研究进展. 生物多样性, 2019, 27 (11): 1184-1195. http://www.biodiversity-science.net/CN/10.17520/biods.2019120

\begin{tabular}{|c|c|c|}
\hline 种 Species & 根状茎 Rhizome & 附生/石生 Epiphytic / Ishio \\
\hline 中华剑蕨 Loxogramme chinensis & 横走 & 石生 \\
\hline \multicolumn{3}{|l|}{ 星蒝属 Microsorum } \\
\hline 羽裂星藃 Microsorum insigne & 横走 & 石生 \\
\hline 膜叶星蒴 Microsorum membranaceum & 横走 & 附生 \\
\hline 有翅星硕 Microsorum pteropus & 横走 & 石生 \\
\hline 星硕 Microsorum punctatum & 横走 & 附生 \\
\hline \multicolumn{3}{|l|}{ 盾葴属 Neolepisorus } \\
\hline 江南星蕨 Neolepisorus fortunei & 横走 & 附生/石生 \\
\hline 显脉星硕 Neolepisorus zippelii & 横走 & 附生 \\
\hline \multicolumn{3}{|l|}{ 假瘤蕨属 Phymatopteris } \\
\hline \multicolumn{3}{|l|}{$\begin{array}{l}\text { 笑裂假溜敛 Phymatopteris oxyloba } \\
\text { 留䓞属 Phymatosorus }\end{array}$} \\
\hline 光亮瘤葓 Phymatosorus cuspidatus & 横走 & 石生 \\
\hline \multicolumn{3}{|l|}{ 鹿角萨属 Platycerium } \\
\hline 鹿角䔊 Platycerium wallichii & 横走 & 附生 \\
\hline \multicolumn{3}{|l|}{ 石韦属 Pyrrosia } \\
\hline 贴生石韦 Pyrrosia adnascens & 攀援 & 附生/石生 \\
\hline 下延石韦 Pyrrosia costata & 横卧 & 附生/石生 \\
\hline 华北石韦 Pyrrosia davidii* & 横卧 & 石生 \\
\hline 纸质石韦 Pyrrosia heteractis & 横走 & 附生/石生 \\
\hline 平滑石韦 Pyrrosia laevis & 横走 & 石生 \\
\hline 石韦 Pyrrosia lingua & 横走 & 附生/石生 \\
\hline 裸叶石韦 Pyrrosia nuda & 横走 & 附生 \\
\hline 钱币石韦 Pyrrosia nummulariifolia & 横走 & 石生 \\
\hline 有柄石韦 Pyrrosia petiolosa & 长而横走 & 石生 \\
\hline 抱树莲 Pyrrosia piloselloides & 长而横走 & 附生 \\
\hline 抱树石韦 Pyrrosia piloselloides & 匍匐 & 附生/石生 \\
\hline 柔软石韦 Pyrrosia porosa & 短而横走 & 附生/石生 \\
\hline 平线石韦 Pyrrosia porosa var. mollissima & 短而横走 & 石生 \\
\hline 相似石韦 Pyrrosia similis & 横卧 & 附生/石生 \\
\hline 石韦一种 Pyrrosia sp. & 长而横走 & 附生 \\
\hline 线毛石韦 Pyrrosia subfurfuracea & 横卧 & 石生 \\
\hline 中越石韦 Pyrrosia tonkinensis & 横卧 & 附生/石生 \\
\hline \multicolumn{3}{|l|}{ 铁角蕨科 Aspleniaceae } \\
\hline \multicolumn{3}{|l|}{ 铁角蕨属 Asplenium } \\
\hline 狭翅巢硕 Asplenium antrophyoides & 直立 & 附生/石生 \\
\hline 华南铁角菜 Asplenium austro-chinense & 横走 & 石生 \\
\hline 毛轴铁角菜 Asplenium crinicaule & 短而直立 & 石生 \\
\hline 水鳖蕨 Asplenium delavayi & 短而直立 & 石生 \\
\hline 剑叶铁角硕 Asplenium ensiforme & 直立 & 附生/石生 \\
\hline 网脉铁角颣 Asplenium finlaysonianum & 直立 & 附生/石生 \\
\hline 厚叶铁角菜 Asplenium griffithianum & 直立 & 石生 \\
\hline 巢硕 Asplenium nidus & 直立 & 附生/石生 \\
\hline 长叶巢蕨 Asplenium phyllitidis & 直立 & 附生/石生 \\
\hline 西南铁角䕋 Asplenium praemorsum & 短而直立 & 石生 \\
\hline 长叶铁角菜 Asplenium prolongatum & 直立 & 石生 \\
\hline 假大羽铁角菜 Asplenium pseudolaserpitiifolium & 斜升 & 石生 \\
\hline 石生铁角硕 Asplenium saxicola & 短而直立 & 石生 \\
\hline 狭叶铁角硕 Asplenium scortechinii & 直立 & 附生/石生 \\
\hline 棕鳞铁角濒 Asplenium yoshinagae & 直立 & 附生/石生 \\
\hline \multicolumn{3}{|l|}{ 膜叶铁角䓞属 Hymenasplenium } \\
\hline 无配膜叶铁角硕 Hymenasplenium apogamum & 长而横走 & 附生/石生 \\
\hline 齿果膜叶铁角蕨 Hymenasplenium cheilosorum & 长而横走 & 石生 \\
\hline 切边膜叶铁角葓 Hymenasplenium excisum & 横走 & 附生/石生 \\
\hline \multicolumn{3}{|l|}{ 鳞毛烣科 Dryopteridaceae } \\
\hline \multicolumn{3}{|l|}{ 实硕属 Bolbitis } \\
\hline 多羽实萨 Bolbitis angustipinna & 短而横走 & 石生 \\
\hline 河口实硕 Bolbitis hekouensis & 短而横走 & 石生 \\
\hline 长叶实鄀 Bolbitis heteroclita & 横走 & 附生/石生 \\
\hline 长耳刺蕨 Bolbitis longiaurita & 短而横走 & 石生 \\
\hline 中华刺蕨 Bolbitis sinensis & 横走 & 附生 \\
\hline \multicolumn{3}{|l|}{ 舌蕨属 Elaphoglossum } \\
\hline 舌瞢一种 Elaphoglossum sp. & 短而横走 & 附生 \\
\hline 华南舌蒝 Elaphoglossum yoshinagae & 短而横走 & 附生/石生 \\
\hline 云南舌硕 Elaphoglossum yunnanense & 横走/斜升 & 附生 \\
\hline \multicolumn{3}{|l|}{ 网藤硕属 Lomagramma } \\
\hline 网藤菜 Lomagramma matthewii & 横走 & 附生/石生 \\
\hline
\end{tabular}


孙晶琦, 陈泉, 李航宇, 常艳芬, 巩合德, 宋亮, 卢华正. 附生蕨类植物的克隆性研究进展. 生物多样性, 2019, 27 (11): 1184-1195. http://www.biodiversity-science.net/CN/10.17520/biods.2019120

\begin{tabular}{|c|c|c|}
\hline 种 Species & 根状茎 Rhizome & 附生/石生 Epiphytic / Ishio \\
\hline \multicolumn{3}{|l|}{ 膜硕科 Hymenophyllaceae } \\
\hline \multicolumn{3}{|l|}{ 假脉蓱属 Crepidomanes } \\
\hline 长柄假脉䕬 Crepidomanes racemulosum & 横走 & 附生 \\
\hline \multicolumn{3}{|l|}{ 毛边蕨属 Didymoglossum } \\
\hline 细柄单叶假脉蕨 Didymoglossum motleyi ${ }^{*}$ & 横走 & 附生/石生 \\
\hline \multicolumn{3}{|l|}{ 膜蕨属 Hymenophyllum } \\
\hline 蕗蒴 Hymenophyllum badium & 横走 & 附生 \\
\hline 长柄蕗硕 Hymenophyllum osmundoides ${ }^{*}$ & 横走 & 附生 \\
\hline 毛叶硕 Pleuromanes pallidum ${ }^{*}$ & 横走 & 附生/石生 \\
\hline \multicolumn{3}{|l|}{ 瓶而属 Vandenboschia } \\
\hline 瓶蕨 Vandenboschia auriculata & 横走 & 附生/石生 \\
\hline 管苞瓶兴 Vandenboschia birmanica & 长而横走 & 石生 \\
\hline \multicolumn{3}{|l|}{ 骨碎补科 Davalliaceae } \\
\hline \multicolumn{3}{|l|}{ 骨碎补属 Davallia } \\
\hline 假脉骨碎补 Davallia denticulata & 横走 & 附生/石生 \\
\hline 大叶骨碎补 Davallia divaricata & 横走 & 附生/石生 \\
\hline 杯盖阴石蓱 Davallia griffithiana & 横走 & 附生/石生 \\
\hline 骨碎补 Davallia mariesii ${ }^{*}$ & 横走 & 附生/石生 \\
\hline 假钻毛藃 Davallia multidentatum & 横走 & 附生/石生 \\
\hline 鳞轴小膜盖蕨 Davallia perdurans & 横走 & 附生 \\
\hline 半圆盖阴石硕 Davallia platylepis & 长而横走 & 附生 \\
\hline 美小膜盖硕 Davallia pulchra & 横走 & 附生/石生 \\
\hline 阴石蕨 Davallia repens & 横走 & 附生/石生 \\
\hline 阔叶骨碎补 Davallia solida & 横走 & 附生/石生 \\
\hline \multicolumn{3}{|l|}{ 石松科 Lycopodiaceae } \\
\hline \multicolumn{3}{|l|}{ 石杉属 Huperzia } \\
\hline 华南马尾杉 Huperzia austrosinica & 簇生 & 附生 \\
\hline 福氏马尾杉 Huperzia fordii & 簇生 & 附生 \\
\hline 椭圆叶马尾杉 Huperzia henryi & 簇生 & 附生 \\
\hline 马尾杉 Huperzia phlegmaria & 簇生 & 附生 \\
\hline 粗粮马尾杉 Huperzia squarrosa & 簇生 & 附生 \\
\hline \multicolumn{3}{|l|}{ 石松属 Lycopodium } \\
\hline 石松 Lycopodium japonicum & 纤细横走 & 石生 \\
\hline \multicolumn{3}{|l|}{ 垂穗石松属 Palhinhaea } \\
\hline 垂穗石松 Palhinhaea cernua & 直立 & 石生 \\
\hline \multicolumn{3}{|l|}{ 藤蕨科 Lomariopsidaceae } \\
\hline \multicolumn{3}{|l|}{ 藤鄀属 Lomariopsis } \\
\hline 藤厤 Lomariopsis cochinchinensis & 蔓生 & 附生/石生 \\
\hline \multicolumn{3}{|l|}{ 碗薕科 Dennstaedtiaceae } \\
\hline \multicolumn{3}{|l|}{ 鳞盖葻属 Microlepia } \\
\hline 鳞盖烣一种 Microlepia sp. & 长而横走 & 附生 \\
\hline 肾烣科 Nephrolepidaceae & & \\
\hline 肾菜属 Nephrolepis & & \\
\hline 肾硕 Nephrolepis cordifolia & 直立 & 附生/土生 \\
\hline 镰叶肾䒴 Nephrolepis falcata & 直立 & 附生 \\
\hline 条薜科 Oleandraceae & & \\
\hline 条葓属 Oleandra & & \\
\hline 光叶条蕨 Oleandra musaefolia & 匍匐 & 附生 \\
\hline 松叶烣科 Psilotaceae & & \\
\hline 松叶蕨属 Psilotum & & \\
\hline 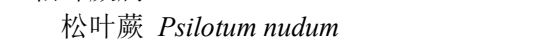 & 横走 & 附生/石生 \\
\hline 卷柏科 Selaginellaceae & & \\
\hline 卷柏属 Selaginella & & \\
\hline 薄叶卷柏 Selaginella delicatula & 直立 & 石生 \\
\hline 充州卷柏 Selaginella involvens & 横走 & 附生/石生 \\
\hline 黑顶卷柏 Selaginella picta & 直立 & 石生 \\
\hline 高雄卷柏 Selaginella repanda & 直立 & 石生 \\
\hline 翠云草 Selaginella uncinata & 直立 & 石生 \\
\hline 叉笨科 Aspidiaceae & & \\
\hline 叉硕属 Tectaria & & \\
\hline 三叉颐 Tectaria subtriphylla & 横走 & 石生 \\
\hline 沙皮硕 Tectaria harlandii & 短而横走 & 石生 \\
\hline 燕尾叉葓 Tectaria simonsii & 直立 & 石生 \\
\hline 爬树葓属 Arthropteris & & \\
\hline 爬树蕨 Arthropteris palisotii & 蔓生 & 附生/石生 \\
\hline
\end{tabular}

